Clim. Past Discuss., 7, 2159-2192, 2011

www.clim-past-discuss.net/7/2159/2011/

doi:10.5194/cpd-7-2159-2011

(c) Author(s) 2011. CC Attribution 3.0 License.

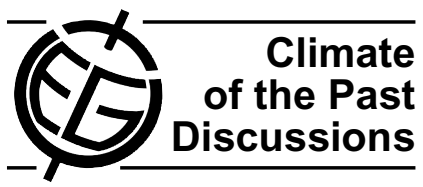

This discussion paper is/has been under review for the journal Climate of the Past (CP).

Please refer to the corresponding final paper in $\mathrm{CP}$ if available.

\title{
Synchronicity of the East Asian Summer Monsoon variability and Northern Hemisphere climate change since the last deglaciation
}

T. Shinozaki ${ }^{1,2,3}$, M. Uchida ${ }^{2}$, K. Minoura ${ }^{1}$, M. Kondo ${ }^{2}$, S. F. Rella ${ }^{2}$, and Y. Shibata $^{2}$

${ }^{1}$ Institute of Geology and Paleontology, Tohoku University, Sendai, Japan

${ }^{2}$ Environmental Chemistry Division, National Institute for Environmental Studies (NIES), Tsukuba, Japan

${ }^{3}$ Life and Environmental Science, University of Tsukuba, Tsukuba, Japan

Received: 2 June 2011 - Accepted: 18 June 2011 - Published: 27 June 2011

Correspondence to: M. Uchida (uchidama@nies.go.jp)

Published by Copernicus Publications on behalf of the European Geosciences Union.

Synchronicity of the East Asian Summer Monsoon

T. Shinozaki et al.

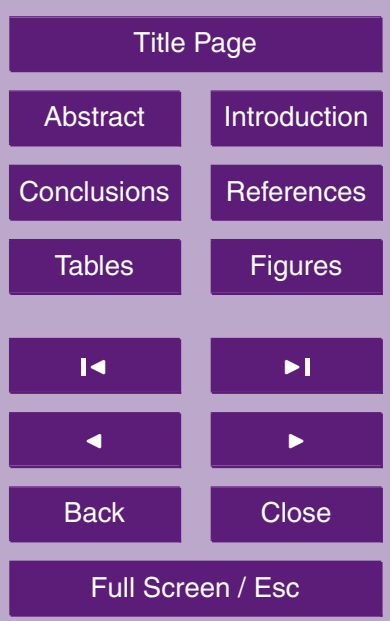

Printer-friendly Version

Interactive Discussion






\section{Abstract}

Understanding of the mechanism of the East Asian Summer Monsoon (EASM) is required for the prediction of climate change in East Asia in a scenario of modern global warming. In this study, we present high-resolution climate records from peat sedi5 ments in Northeast Japan to reconstruct the EASM variability based on peat bulk cellulose $\delta^{13} \mathrm{C}$ since the last deglaciation. We used a $8.8 \mathrm{~m}$ long peat sediment core collected from the Tashiro Bog, Northeast Japan. Based on $42{ }^{14} \mathrm{C}$ measurements, the core bottom reaches $\sim 15.5 \mathrm{ka}$. $\delta^{13} \mathrm{C}$, accumulation rate and accumulation flux timeseries correlate well to Greenland ice core $\delta^{18} \mathrm{O}$ variability, suggesting that the climate record in Northeast Japan is linked to global climate changes. The $\delta^{13} \mathrm{C}$ record at Tashiro Bog and other paleo-EASM records at Northeast and Southern China consistently demonstrate that hydrological environments were spatially different in mid-high and mid-low latitude regions over the last $15.5 \mathrm{kyr}$. During global cooling (warming) periods, mid-high and mid-low latitude regions were characterized by wet (dry) and dry 15 (wet) environments, respectively. We suggest that these climatic patterns are related to the migration of the EASM-related rain belt during global climate changes, as a consequence of variations in intensity and location of both the Intertropical Convergence Zone (ITCZ) and the Western Pacific Subtropical High (STH). The location of the rain belt largely influences the East Asian hydrological environment. Our $\delta^{13} \mathrm{C}$ time-series are characterized by a $1230 \mathrm{yr}$ throughout the Holocene and a $680 \mathrm{yr}$ periodicity during the early Holocene. The $1230 \mathrm{yr}$ periodicity is in agreement with North Atlantic icerafted debris (IRD) events, suggesting a teleconnection between the Northeast Japan and the North Atlantic during the Holocene. In addition, it is the first evidence that the Bond events were recorded in terrestrial sediment in Japan. On the other hand, the $680 \mathrm{yr}$ periodicity between 10.0 and $8.0 \mathrm{kyr}$ is consistent with a prominent $649 \mathrm{yr}$ solar activity cycle, suggesting that solar activity affected EASM precipitation during the Hypsithermal, when orbital-scale solar insolation was at a maximum in the Northern Hemisphere.
7, 2159-2192, 2011

\section{Synchronicity of the East Asian Summer Monsoon}

T. Shinozaki et al.

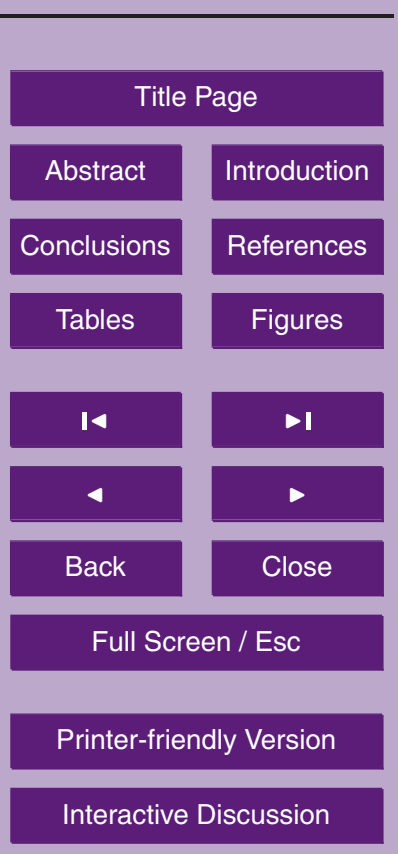




\section{Introduction}

The East Asian Summer Monsoon (EASM) is one of the most important components that influence East Asian climate. East Asia, which is home for about one third of the world population, is an economically fast growing region. People in East Asia depend 5 on food supply supported by monsoonal precipitation. However, monsoonal rainfall fluctuations often cause devastating floods and/or droughts. Reliable predictions of the EASM variability under a scenario of global warming are therefore of foremost interest. Besides modeling efforts, the reconstruction of the behavior of the paleo-EASM during past global climate change is necessary to predict future climate in East Asia.

10 The continuous history of the paleo-EASM become understanding from the highresolution analyses of stalagmite $\delta^{18} \mathrm{O}$ in Southern China since late Pleistocene to Holocene (Wang et al., 2001, 2005; Yuan et al., 2004). During the last deglaciation and the Holocene, the stalagmite $\delta^{18} \mathrm{O}$ is well synchronous with the $\delta^{18} \mathrm{O}$ records of Greenland ice core, suggesting that the East Asian region is influenced by global 15 climate change (Yuan et al., 2004; Wang et al., 2005). The stalagmite $\delta^{18} \mathrm{O}$ records are from the mid-low latitude region in East Asia; there are, however, only few studies from the East Asian mid-high latitudes in high-resolution time scale.

Peat sediments constitute an important terrestrial archive for reconstructing continental paleoenvironmental histories (Jackson et al., 2010). In general, a continuous record of terrestrial environments is difficult to reconstruct from terrestrial sediments, because terrestrial sediments are eroded and transported away by wind or water. Therefore, marine sediments were often used in paleoclimatology. However, it is difficult to reconstruct environment and climatic changes from marine sediments in high resolution during recent periods such as the Holocene epoch due to low accuthe Holocene epoch: the hydrological environments, in which peat forms, encourage growth of vascular plants and retard decomposition of their remains to produce thick accumulations of organic-rich material that can be used for high resolution (decadal

\section{Synchronicity of the East Asian Summer Monsoon}

T. Shinozaki et al.
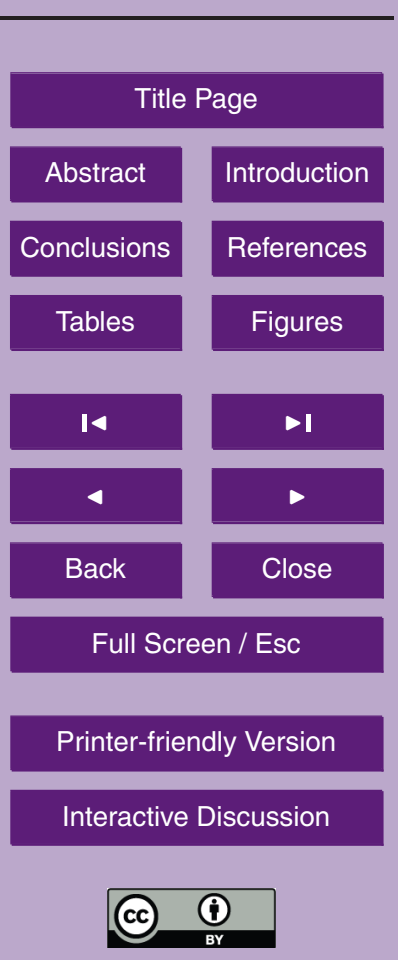
to centennial time-scale) palaeoenvironmental reconstructions. The balance between precipitation and evapotranspiration in a particular bog controls the kind and abundance of bog plants and their preservation as peat. Climate changes modify this balance by altering the precipitation of water and its temperature-sensitive evaporation. 5 These changes can be recorded in the organic geochemical and paleoclimatic proxies of the peat layers that were deposited at different stages in the bog history.

A lot of proxies obtained from peat sediment have been used for climatic reconstruction, such as $\delta^{13} \mathrm{C}$ (Sukumar et al., 1993; Hong et al., 2001, 2003, 2005; Zhu et al., 2009; Hong et al., 2010a), $\delta^{18} \mathrm{O}$ (Siegenthaler and Oeschger, 1980; Rozanski et al., 10 1992; Aucour et al., 1996; Hong et al., 2000, 2009; Ménot-Combes et al., 2002; Daley et al., 2010), $\delta \mathrm{D}$ (Schiegl, 1972; Brenninkmeijer et al., 1982), $\delta^{15} \mathrm{~N}$ (Novak et al., 1999; Asada et al., 2005; Jones et al., 2010) and stable isotopic ratios of plant wax (Zhou et al., 2005, 2010; Zheng et al., 2007; Seki et al., 2009; Yamamoto et al., 2010a, b). We used $\delta^{13} \mathrm{C}$ to reconstruct the hydrological environment. The amount of rainfall is negatively correlated to plant $\delta^{13} \mathrm{C}$ value: the larger the amount of rainfall, the smaller the $\delta^{13} \mathrm{C}$ value (Hong et al., 2010b) (for more details see Sect. 3.1)

In this study, we aim to reconstruct the EASM variability and its linkages with the global climate system during the last deglaciation and Holocene in Northeast Japan, using a $8.8 \mathrm{~m}$ long peat sediment core. We used bulk sediments ${ }^{14} \mathrm{C}$ for dating and bulk cellulose $\delta^{13} \mathrm{C}$ as a proxy indicator for EASM intensity. To reconstruct the paleo-EASM variability, our records were compared with other EASM records. We compared our results with the migration pattern of the Intertropical Convergence Zone (ITCZ) to further discuss the EASM mechanism. We also revealed the EASM-related climatic periodicity and discussed the interaction between the EASM and the Northern Hemisphere
7, 2159-2192, 2011

\section{Synchronicity of the East Asian Summer Monsoon}

T. Shinozaki et al.

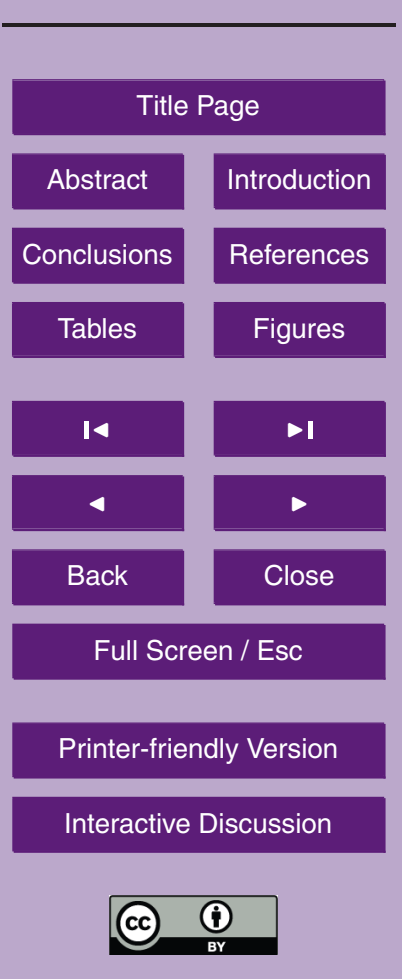




\section{Study area and sediment samples}

\subsection{Geographyical setting}

$7,2159-2192,2011$

The Tashiro Bog $\left(40^{\circ} 41^{\prime} \mathrm{N}, 144^{\circ} 55^{\prime} \mathrm{E}\right)$ is located in Northeast Japan at an altitude of $570 \mathrm{~m}$ above sea level (Fig. 1). Records from the meteorological institute 5 (http://www.jma.go.jp/jma/index.html) of Aomori City $\left(40^{\circ} 49^{\prime} \mathrm{N}, 140^{\circ} 45^{\prime} \mathrm{E}\right.$; about $18 \mathrm{~km}$ northwest of our core site; Fig. 1c) between 1971 and 2000 show that annual mean atmospheric temperatures, annual precipitation and annual mean relative humidity are $10.1^{\circ} \mathrm{C}, 1290 \mathrm{~mm}$ and $75 \%$, respectively. The Tashiro Bog is covered by heavy snow in winter. After fast completion of the plant growth process during summer, the plants die fast with the arrival of the long cold season. It can be seen that the degree of humification of the dead plants is lower and the plant remains preserved in peat deposition are more intact. As the Tashiro Bog does not receive river input and is not drained by rivers (Fig. 1d), the swamp water originates from precipitation. Therefore the formed peat layer was not disturbed.

\subsection{Sediment sample}

The $880 \mathrm{~cm}$ long core was drilled in the center of the bog (Fig. 1d) using a thin-walled core sampler. This core is generally composed of peat with two sand layers (between 841 and $820 \mathrm{~cm}$ depth, and 338 and $328 \mathrm{~cm}$ depth), a clay layer (between 798 and $780 \mathrm{~cm}$ depth) and five tephra layers (between 880 and $849 \mathrm{~cm}$ depth, 845 and $841 \mathrm{~cm}$ depth, 347 and $338 \mathrm{~cm}$ depth, 76 and $65 \mathrm{~cm}$ depth, and 62 and $58 \mathrm{~cm}$ depth) intercalated (Fig. 2).

\section{Analytical procedures}

The collected sediment core was cut into $1.0 \mathrm{~cm}$ intervals. We loaded sediment samples into $1 \mathrm{~cm}^{3}$ polycarbonate cubes, where they were left at least two months for drying

\section{Synchronicity of the East Asian Summer Monsoon}

T. Shinozaki et al.

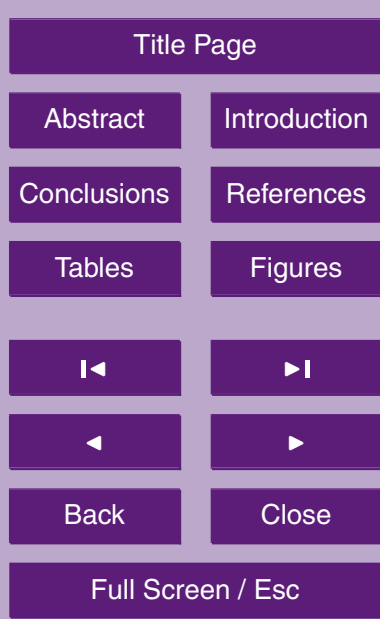

Printer-friendly Version

Interactive Discussion

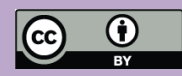


at room temperature. After drying, we weighed the samples to determine their dry bulk density (DBD) $\left(\mathrm{g} \mathrm{cm}^{-3}\right)$. Prior to following analysis, samples were homogenized using mortar and pestle.

\subsection{Stable carbon isotope ratios of peat cellulose}

5 The stable carbon isotopic ratio of peat cellulose $\left(\delta^{13} \mathrm{C}_{\text {cellulose }}\right)$ is used as a proxy indicator for evaluating atmospheric humidity (e.g. Hong et al., 2010b). The $\delta^{13} \mathrm{C}_{\text {cellulose }}$ values are mostly influenced by humid environment in summer when the plant grows (Hong et al., 2001). At least for the last $15.5 \mathrm{kyr}$ peat sediments of the Tashiro Bog are a mixture consisting of different species of C3 plants, for example Betula, Fagus and 10 Quercus (Yoshida and Takeuti, 2009). Vascular plants respond to variations in water availability and relative humidity by regulating the opening or closing of leaf stomata. When the plant was relatively dry and the hyaline cells were nearly devoid of water, $\mathrm{CO}_{2}$ diffusion to the chloroplast is relatively high. Carbon fixation is limited by reduced metabolic activity and the $\delta^{13} \mathrm{C}_{\text {cellulose }}$ values are dominated by carbon isotope 15 fractionation due to the photosynthetic enzyme. The desiccation effect results in an increase in fractionation against ${ }^{13} \mathrm{CO}_{2}$ during photosynthesis (Williams and Flanagan, 1996). In contrast, when the plant was relatively wet in response to sufficient water availability, the hyaline cells are filled with water. Diffusion of $\mathrm{CO}_{2}$ to the chloroplasts is reduced and $\delta^{13} \mathrm{C}_{\text {cellulose }}$ values are predominantly influenced by stable carbon isotope 20 fractionation (Ménot and Burns, 2001). Consequently, the smaller the water reservoir surrounding the chloroplast, the lower the $\delta^{13} \mathrm{C}_{\text {cellulose }}$, and vice versa (Moschen et al., 2009). Therefore $\delta^{13} \mathrm{C}_{\text {cellulose }}$ variation indirectly indicates fluctuation of humidity and precipitation during the plant growing season (summer), and can be used to reconstruct the past water environments. Especially, because precipitation are largely restricted by

We employed the method of Shinozaki et al. (2011), to extract cellulose from the peat sediments. The method of Shinozaki et al. (2011) is a modified standard extraction

7, 2159-2192, 2011

\section{Synchronicity of the East Asian Summer Monsoon}

T. Shinozaki et al.
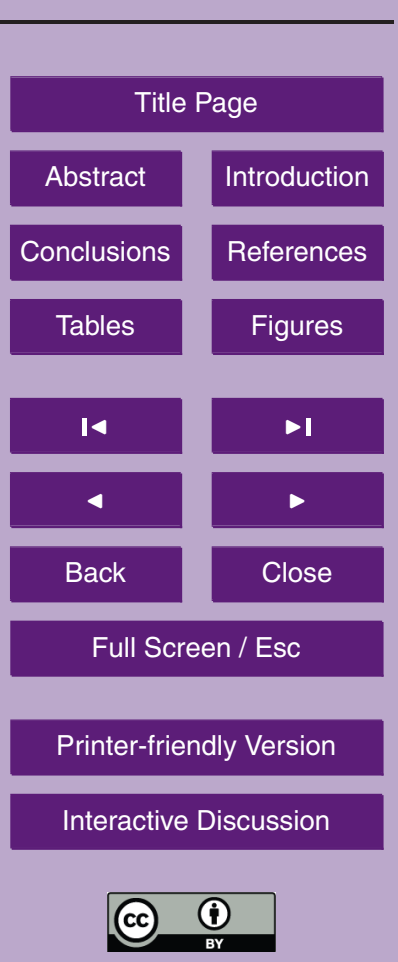
method (Green, 1963; Loader et al., 1997). The standard method is not used for peat sediments but for tree-rings. Shinozaki et al. (2011) compared and discussed various cellulose extraction methods for peat sediments to find the most suitable one. Accordingly, we used the following method: First, homogenized bulk sediments were 5 weighed and treated following an Acid - Alcali - Acid procedure $\left(5.0 \%, 60^{\circ} \mathrm{C}, 2 \mathrm{~h}\right.$, respectively) to remove contaminating carbonate and humic acid. Second, the treated samples were reacted with $7 \% \mathrm{NaClO}_{2}\left(60^{\circ} \mathrm{C}\right)$ to remove lignin. Finally, samples were reacted with $17 \% \mathrm{NaOH}$ at room temperature to remove hemicellulose, and freezedried.

10 The peat cellulose $\delta^{13} \mathrm{C}$ was measured at least duplicate using an EA/IRMS (Elemental Analyzer/ Isotope Ratio Mass Spectrometer; FLASH 2000/DELTA V ADVANTAGE, Thermo Fisher Scientific) at the National Institute for Environmental Studies (NIES) in Tsukuba, Japan. Acetanilide $\left(\delta^{13} \mathrm{C}=-30.99 \%\right.$ ) was used as internal standard for drift corrections. The overall precision of replicate analysis is estimated to be 15 better than $\pm 0.1 \%$.

\subsection{Radiocarbon dating}

We conducted 42 radiocarbon analyses of bulk sediment sample. The graphitization of bulk sediments were carried out according to a procedure by Uchida et al. (2005) and Uchida et al. (2008), and the method is as follow: homogenized bulk sediment samples were combusted in sealed quartz tubes (with $\mathrm{CuO}$ ), and the $\mathrm{CO}_{2}$ produced was purified and graphitized by reduction with $\mathrm{H}_{2}$ using Fe powder as a catalyst. The graphite cathodes were then loaded into the AMS at NIES-TERRA in Tsukuba, Japan (Uchida et al., 2004). The measured ${ }^{14} \mathrm{C}$ values were calibrated to calendar age using the calibration program CALIB-6.0 (http://calib.qub.ac.uk/calib/). And then, we regard
7, 2159-2192, 2011

\section{Synchronicity of the East Asian Summer Monsoon}

T. Shinozaki et al.
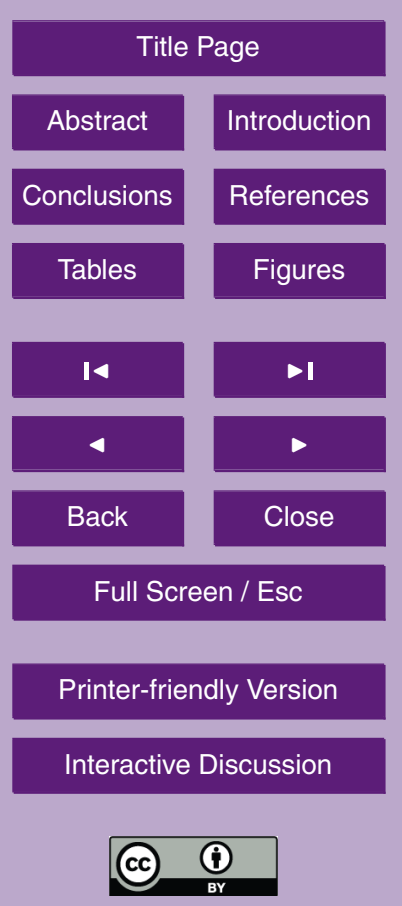


\section{Results}

\subsection{Radiocarbon dating and peat accumulation rate}

The ${ }^{14} \mathrm{C}$ results of bulk sediments are given in Table 1 and Fig. $2 \mathrm{a}$. We measured not only bulk sediment but also bulk cellulose, however, the differences between two 5 materials are up to $\sim 620 \mathrm{yr}$ during the last deglaciation (Shinozaki et al., 2011). Chronology of this core was established by 42 bulk sediment samples. The bottom of the core (between 849 and $848 \mathrm{~cm}$ depth) corresponds to $15407 \pm 242 \mathrm{cal} \mathrm{yr} \mathrm{BP}$. From this ${ }^{14} \mathrm{C}$ age, the tephra layer of the bottom of the core (below $849 \mathrm{~cm}$ depth) seems to be the Towada-Hachinohe tephra (To-H; about 15521 cal yr BP; Horiuchi et al., 2007). ${ }^{14} \mathrm{C}$ ages furthermore suggest that the tephra layers between 347 and $338 \mathrm{~cm}$ depth, 76 and $65 \mathrm{~cm}$ depth, and 62 and $58 \mathrm{~cm}$ depth correspond to the TowadaCuseri tephra (To-Cu; $6188 \pm 292$ cal yr BP; Hayakawa, 1983), the Towada-a tephra (To-a; $990 \pm 195$ cal yr BP; Hayakawa, 1985), and the Baekdu-san-Tomakomai tephra (B-Tm; $985 \pm 20$ cal yr BP; Horn and Schmincke, 2000), respectively.

Considerably high accumulation rates of $106.9 \mathrm{~cm} \mathrm{kyr}^{-1}, 164.4 \mathrm{~cm} \mathrm{kyr}^{-1}$ and $172.3 \mathrm{~cm} \mathrm{kyr}^{-1}$ occur between 795 and $768 \mathrm{~cm}, 667$ and $650 \mathrm{~cm}$, and 604 and $564 \mathrm{~cm}$, respectively.

\subsection{TOC and DBD}

Temporal variations of TOC and DBD are shown in Fig. 2b, c. Between 849 and $640 \mathrm{~cm}$ and/or mud layers. Between 640 and $550 \mathrm{~cm}$ depth, TOC gradually increases and DBD decreases, indicating a decrease in the amount of minerals in this interval that is characterized by a low degree of decomposition of organic materials. In the upper $550 \mathrm{~cm}$, TOC and DBD are relatively constant, although they slightly fluctuate.

7, 2159-2192, 2011

\section{Synchronicity of the East Asian Summer Monsoon}

T. Shinozaki et al.
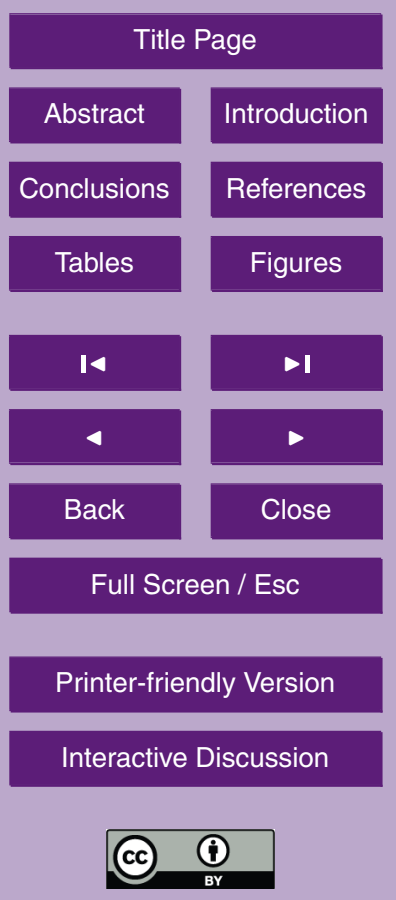


\section{Discussions}

\subsection{Climate change in Northeast Japan}

In Fig. 3b, c, d, we show peat accumulation rate $\left(\mathrm{cm} \mathrm{kyr}^{-1}\right)$, peat accumulation fluxes $\left(\mathrm{mgC} \mathrm{cm}{ }^{-2} \mathrm{kyr}^{-1}\right.$ ) and $\delta^{13} \mathrm{C}(\%)$ time series at the Tashiro Bog for the period from 516.0 cal kyr BP to present. In order to isolate the influence of different sediment materials, we have calculated the peat accumulation fluxes from the TOC, DBD and accumulation rate as follows: accumulation flux $\left(\mathrm{mgC} \mathrm{cm}^{-2} \mathrm{kyr}^{-1}\right)=\mathrm{TOC}\left(\mathrm{mgC} \mathrm{g}^{-1}\right) \times \mathrm{DBD}$ $\left(\mathrm{g} \mathrm{cm}^{-1}\right) \times$ accumulation rate $\left(\mathrm{cm} \mathrm{kyr}^{-1}\right)$. In order to isolate the influence of atmospheric $\delta^{13} \mathrm{C}$ variability, we deducted the difference between the present $(-8 \%)$ and past val10 ues (Leuenberger et al., 1992; Elsig et al., 2009; Fig. 3d), and defined calculated $\delta^{13} \mathrm{C}_{\text {cellulose }}$ as $\delta^{13} \mathrm{C}^{\prime}$.

Temporal variation of accumulation rate, accumulation flux and the $\delta^{13} \mathrm{C}$ ' for the past $15.5 \mathrm{kyr}$ are relatively similar (Fig. 3b, c, d). Coeval high peaks of accumulation rates/fluxes and $\delta^{13} \mathrm{C}^{\prime}$ values suggest that the plant growing season (summer) might 15 have been warm and dry. On the other hand, periods of coeval low values might suggest cold and wet conditions.

The variations in our records correspond well to the $\delta^{18} \mathrm{O}$ records of the GISP2 ice core (Stuiver and Grootes, 2000) in the period between 15.5 and $8.0 \mathrm{ka}$. The peak positions of low accumulation rates, accumulation fluxes and $\delta^{13} \mathrm{C}^{\prime}$ values in Tashiro Bog between 15.5 and $14.9 \mathrm{ka}, 14.1$ and $13.7 \mathrm{ka}, 12.5$ and $11.5 \mathrm{ka}$, and 8.4 and $8.0 \mathrm{ka}$ seem to correspond to cold periods, namely the Oldest Dryas, the Older Dryas, the Younger Dryas and the $8.2 \mathrm{ka}$ event, respectively. In addition, according to the $\delta^{13} \mathrm{C}^{\prime}$ values, the Oldest Dryas (between 15.5 and $14.9 \mathrm{ka}$ ) might have been characterized by relatively wetter climatic conditions than the Younger Dryas (between 12.5 and $11.5 \mathrm{ka}$ ) around Northeast Japan. On the other hand, coeval peaks of high accumulation rates, accumulation fluxes and $\delta^{13} \mathrm{C}^{\prime}$ values in Tashiro Bog between 14.9 and $14.1 \mathrm{ka}, 13.7$ and $12.5 \mathrm{ka}$, and 11.5 and $11.2 \mathrm{ka}$ seem to correspond to warm periods, namely the

\section{Synchronicity of the East Asian Summer Monsoon}

T. Shinozaki et al.
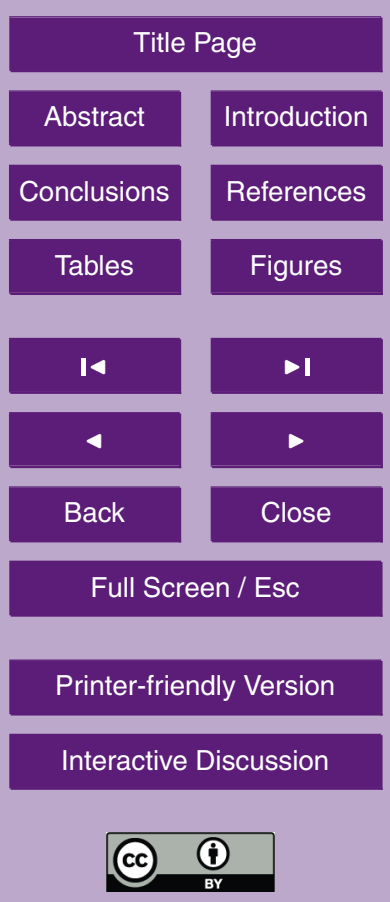
Bølling, the Allerød and the Preboreal, respectively. During warm periods, plant productivity and deposition are larger than during cold periods due to stronger photosynthetic activity. Therefore, accumulation rates are high only during warm periods, when plant deposition largely exceeds organic decomposition. Thus, high accumula5 tion rates and fluxes during warm periods are reasonable and suggest that the Tashiro Bog was affected by global climate change. Also, alkenone SSTs in marine sediments of the Northwest Pacific off Shimokita rose from about 7.5 to $20^{\circ} \mathrm{C}$ from the termination of the Younger Dryas to the early-Holocene (M. Uchida, personal communication). Apparently, the Northwest Pacific regions was generally influenced by abrupt global 10 climate changes, and $\delta^{13} \mathrm{C}^{\prime}$ in Tashiro Bog seems to have a significant potential as an indicator for paleoclimatic changes.

\subsection{Linkage with the paleo-EASM variability}

There are numerous studies on EASM variability based on stalagmite $\delta^{18} \mathrm{O}$ (Wang et al., 2001; Yuan et al., 2004; Dykoski et al., 2005; Wang et al., 2005; Hu et al., 2008; 15 Wang et al., 2008; Rohling et al., 2009), peat cellulose $\delta^{13} \mathrm{C}$ and $\delta^{18} \mathrm{O}$ (Hong et al., 2003, 2005, 2009; Hong et al., 2010a), stable isotopic ratios of plant wax in peat sediments (Zhou et al., 2005; Zheng et al., 2007; Seki et al., 2009; Yamamoto et al., 2010a, b), geochemical data in lake sediments (Rhodes et al., 1996; Schettler et al., 2006), pollen data in lake sediments (Jarvis, 1993; Nakagawa et al., 2003, 2006; Stebich et 20 al., 2009) and stable isotopic ratios in marine sediments (Wang et al., 1999; Kubota et al., 2010). We compared our peat cellulose $\delta^{13} \mathrm{C}$ data (Fig. 4c) with the stalagmite $\delta^{18} \mathrm{O}$ records from Hulu Cave (Wang et al., 2001) and Dongge Cave (Yuan et al., 2004) (Figs. 1b, 4b), which reflect paleo-EASM variability, and with the peat cellulose $\delta^{13} \mathrm{C}$ records from the Hani peat bog in Northeast China (Hong et al., 2005; Fig. 1b, 25 4d) and the Hongyuan peat bog in Southern China (Hong et al., 2003; Figs. 1b, 4e). Stalagmite $\delta^{18} \mathrm{O}$ variability corresponds well to our $\delta^{13} \mathrm{C}^{\prime}$ variability especially during the last deglaciation, although the low $\delta^{13} \mathrm{C}^{\prime}$ during the Older Dryas in Tashiro Bog are not seen in stalagmite $\delta^{18} \mathrm{O}$. However, the timing of $\delta^{18} \mathrm{O}$ anomaly recorded from
7, 2159-2192, 2011

\section{Synchronicity of the East Asian Summer Monsoon}

T. Shinozaki et al.

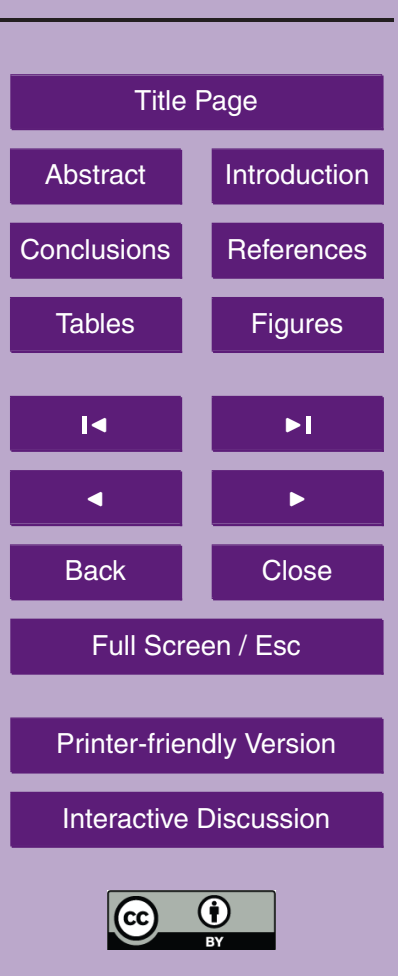


Hani Bog also corresponds to the Older Dryas period (Hong et al., 2009). Although the Older and/or Oldest Dryas are not obviously shown in both stalagmite $\delta^{18} \mathrm{O}$ at Southern China and ice core $\delta^{18} \mathrm{O}$ of GISP2, peat sediment seems to be able to record such climate change. These correspondences between stalagmite $\delta^{18} \mathrm{O}$ and $\delta^{13} \mathrm{C}^{\prime}$ suggest 5 that the climate around Northeast Japan is largely influenced by the EASM. However, while high (low) $\delta^{13} C^{\prime}$ events at Tashiro Bog suggest dry (wet) climate around Northeast Japan, coeval high (low) stalagmite $\delta^{18} \mathrm{O}$ of Hulu and Dongge Cave during the same periods suggest that precipitation was increased (decreased) around Southern China. This anti-phase variability suggests a latitudinal effect on climate in East Asia. 10 This hypothesis is supported by peat cellulose $\delta^{13} \mathrm{C}$ data of the Hani and the Hongyuan Bog: To reconstruct the paleo-EASM variability during the last $12 \mathrm{kyr}$, Hong et al. (2005) and Hong et al. (2003) used peat bulk cellulose $\delta^{13} \mathrm{C}$ and $\delta^{13} \mathrm{C}$ of Carex mulieensis cellulose, respectively. The $\delta^{13} \mathrm{C}^{\prime}$ variability at Tashiro Bog is similar to the $\delta^{13} \mathrm{C}$ of Hani Bog (Fig. 4d), suggesting that wet climatic conditions prevailed in the mid-high latitudes 15 during cold periods. Therefore the mid-high latitude regions, between Northeast China and Northeast Japan appear to be dominantly affected by the EASM during cold periods. On the other hand, the $\delta^{13} \mathrm{C}$ records at the Hongyuan Bog show an anti-phase relationship with our records (Fig. 4e), and indicate dry climatic condition during cold periods and wet condition during warm periods in Southern China. We conclude from our comparisons of $\delta^{13} \mathrm{C}^{\prime}$ with $\delta^{13} \mathrm{C}$ records at the Hani and Hongyuan Bog that the mechanism of climate changes in these regions differ between mid-low and mid-high latitudes. While in the mid-high latitude regions of East Asia climate seems to have been relatively dry during global warming periods such as the Preboreal, the Bølling and the Allerød, relatively wet conditions may have prevailed during global cooling pe25 riods such as the $8.2 \mathrm{ka}$ event and the Younger Dryas. In the mid-low latitudes of East Asia, on the other hand, it may have been wetter during warm periods, and drier during cold periods.

We summarized research about the hydrological environment in East Asia in relation with the EASM during cold periods in Table 2 and Fig. 5, which suggests wetter
7, 2159-2192, 2011

\section{Synchronicity of the East Asian Summer Monsoon}

T. Shinozaki et al.

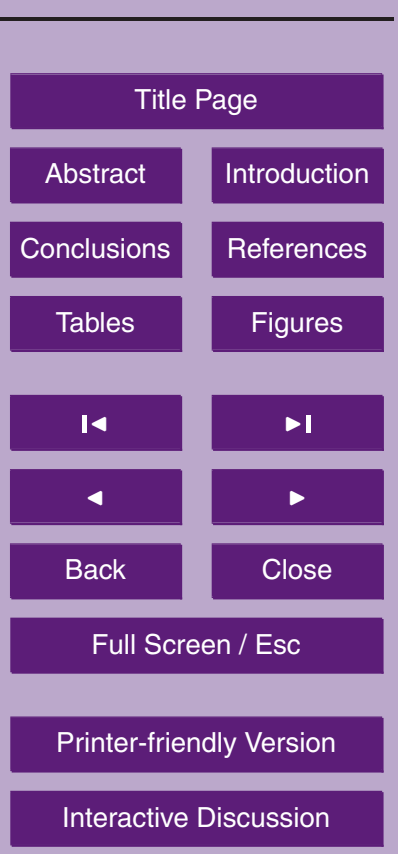


conditions in the Northern China and the Northern Japan (An et al., 1993; Zhou et al., 1996; Hong et al., 2005; Nakagawa et al., 2006; Ishiwatari et al., 2009; Seki et al., 2009; Yamaguchi et al., 2010; Zhou et al., 2010), and drier conditions in Central and Southern China, the South China Sea and the East China Sea (Wang et al., 1999, 5 2001; Hong et al., 2003; Zhao et al., 2003; Yuan et al., 2004; Schettler et al., 2006; Zheng et al., 2007; Stebich et al., 2009; Kubota et al., 2010; Wei et al., 2010).

However, the $\delta^{13} \mathrm{C}$ data in Hani Bog (Hong et al., 2005) show opposite climatic patterns compared to records of geochemical data (Schettler et al., 2006) and pollen data (Stebich et al., 2009) in Lake Sihailongwan near Hani Bog. It was suggested that this 10 discrepancy would be due to relative increase in the contribution of Sphagnum species that could have resulted in changes of $\delta^{13} \mathrm{C}$ change during this period (Yamamoto et al., 2010b; Schettler, 2011). However, the influence of an increased relative contribution of Sphagnum species in peat sediments of the Hani Bog on peat cellulose $\delta^{13} \mathrm{C}$ seems to be negligible (Hong et al., 2011). In addition, the records of $\delta \mathrm{D}$ of plant 15 wax $n$-alkanes (Seki et al., 2009), elevated $n$-alkane $P_{a q}$ values and $\mathrm{C}_{23} / \mathrm{C}_{29}$ ratios (Zhou et al., 2010) in the Hani Bog indicate the wetter climatic conditions during the Younger Dryas, consistent with the $\delta^{13} \mathrm{C}$ results in Hani Bog. Accordingly, Northeast China seems to have experienced increased precipitation during the Younger Dryas, although further research is necessary to confirm this interpretation. Our results on peat cellulose $\delta^{13} \mathrm{C}$ are thus conform with most previous multi-proxy analyses strengthening the hypothesis of a precipitation boundary reaching from Central China to Japan.

\subsection{Mechanism of the presence of the precipitation boundary}

Which processes restrict EASM variability? We propose that changes in atmospheric circulation largely affected the variability of EASM intensity. Previous paleoclimate reNorthern Hemisphere (Ding et al., 1992; Porter and An, 1995; Sirocko et al., 1996; Thompson et al., 1997; Liu and Ding, 1998; Heslop et al., 1999; Wang et al., 2001; Yuan et al., 2004; Dykoski et al., 2005; Oppo and Sun, 2005) when the ITCZ tends to

\section{Synchronicity of the East Asian Summer Monsoon}

T. Shinozaki et al.

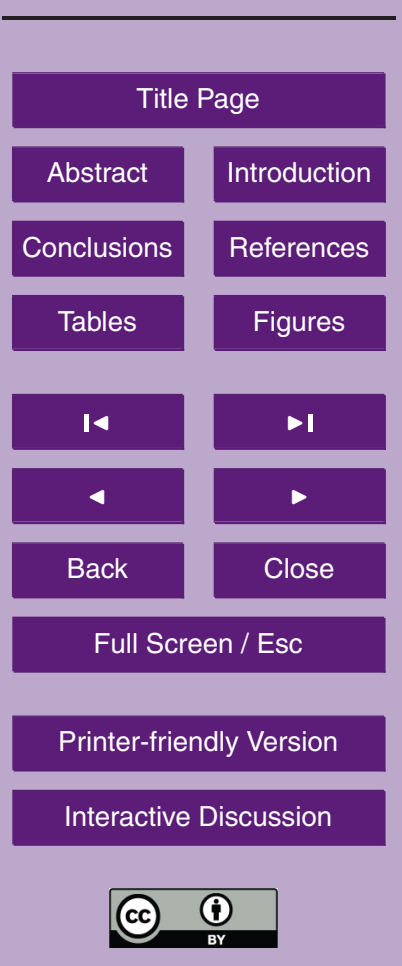


move southward (Hughen et al., 1996; Haug et al., 2001; Yancheva et al., 2007) as it does during El Niño years (Koutavas et al., 2002; Cane, 2005; Ivanochko et al., 2005). The mechanism is as follows: When SSTs in the Equatorial Pacific take on an EI Niñolike pattern (warm SSTs extend to the Eastern Equatorial Pacific due to weakening of 5 easterly trade winds), the ITCZ migrates southward due to strong sea level pressure in the Eastern Equatorial Pacific (Fedorov and Phillander, 2000; Cane, 2005). In association with southward migration of the ITCZ and weaker atmospheric circulations, both the Western Pacific Subtropical High (STH) and EASM tend to weaken. On the other hand, when SSTs in the Equatorial Pacific take on a La Niña-like pattern (in10 crease of the Western Equatorial Pacific SSTs due to strengthening of the easterly trade winds), the ITCZ migrates northward due to the strong sea level pressure in the Western Equatorial Pacific. In association with a northward migration of the ITCZ and stronger atmospheric circulations, both the STH and EASM intensify due to strong convection in the Western Tropics. In fact, the migration of the ITCZ reconstructed from 15 the Ti contents of in a sediment core from the Cariaco basin (Haug et al., 2001) is well synchronous to EASM variability (Fig. 4b) (Hastenrath and Greischar, 1993; Yancheva et al., 2007).

Thus how may we explain the anti-phased paleoclimate states in East Asia (Fig. 5)? We propose a link between the EASM, the ITCZ and the location of the rain belt. During global warming periods (Fig. 6b), equatorial SSTs tend to be high leading to a La Niña-like pattern, associated with a northward migration of the ITCZ and the STH. As a result, both the EASM and STH intensity become stronger. A strong STH positioned in the subtropical Northwest Pacific, close to Japan, impedes the formation of a rain belt in the mid-high latitudes of East Asia. The rain belt is therefore restricted to Southeast 25 Asia: the mid-low latitude regions experience enhanced precipitation, while the midhigh latitude regions remain relatively dry. On the other hand, equatorial SSTs tend to be low during global cooling periods (Fig. 6c), and take on an EI Niño-like pattern associated with a southward migration of the ITCZ and STH. As a result, both the EASM and STH intensity weaken. A weak STH positioned far from Japan allows the rain
7, 2159-2192, 2011

\section{Synchronicity of the East Asian Summer Monsoon}

T. Shinozaki et al.
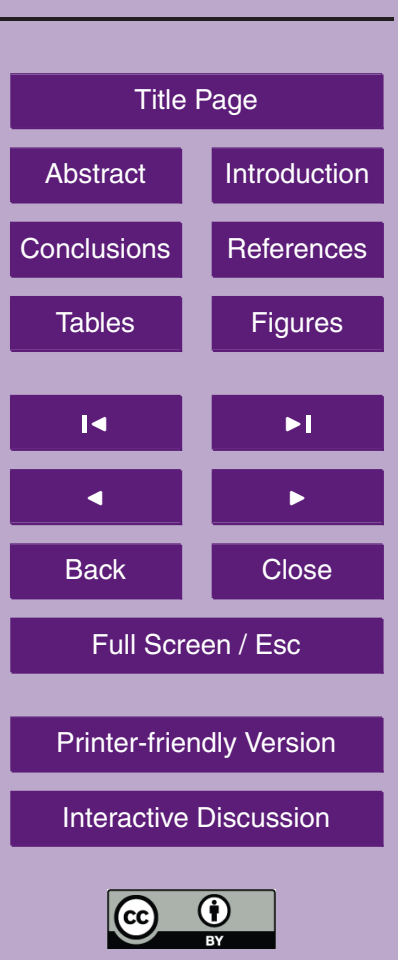
belt reaching Northeast China and Japan. The rain belt, therefore, dominantly forms in Central China and Japan: the mid-high latitudes experience enhanced precipitation while the mid-low latitudes remain relatively dry. We thus suggest that the different hydrological environments in the mid-high and mid-low latitudes are a consequence of 5 the migration of the rain belt associated with the EASM, ITCZ and STH in response to global climate changes.

\subsection{Millennial-scale climate changes in East Asia}

Two power spectral analyses for the last $12 \mathrm{kyr}$ show periodic changes of $\delta^{13} \mathrm{C}^{\prime}$ from the Tashiro Bog. The Blackman Tuckey method using AnalySeries 2.0 (Paillard et al., 10 1996) reveals 6 periodicities ranging from $580 \mathrm{yr}$ to $8470 \mathrm{yr}$ (Fig. 7a). We exclude the $8470 \mathrm{yr}$ periodicity because it is too large compared to our studied time window of $12000 \mathrm{yr}$. To cross-check these periodicities and to specify the terms of periodicity, we conducted another power spectral analysis, Wavelet Analysis (Torrence and Compo, 1998; http://ion.researchsystems.com/IONScript/wavelet/). It shows two characteristic 15 features (Fig. $7 \mathrm{~b}$ ), one is a $\sim 1230 \mathrm{yr}$ periodicity throughout the Holocene, and the other a strong periodicity ranging from 250 to $750 \mathrm{yr}$ between 10.0 and $8.0 \mathrm{ka}$. From the results of the two spectral analyses, we conclude that there exists one long periodicity (1230 yr), which is evident all through the Holocene, and two short periodicities (580 yr and $680 \mathrm{yr}$ ) evident only during the early Holocene.

20 The $1230 \mathrm{yr}$ periodicity can be compared to Bond events, exhibit a distinct pacing on millennial-scale during the Holocene in the high-latitude North Atlantic that might be related to reduced North Atlantic Deep Water formation due to the melting iceberg armadas launched from the Hudson Straits presumably as the results of a collapse of the Hudson Bay lobe of the Laurentide ice sheet (Bond et al., 1997, 2001). These

nine abrupt ocean surface cooling events show a periodicity of about $1470 \pm 500 \mathrm{yr}$ (Bond et al., 1997), which is similar to the $1230 \mathrm{yr}$ periodicity of $\delta^{13} \mathrm{C}^{\prime}$. In fact, $\delta^{13} \mathrm{C}^{\prime}$ in the Tashiro Bog show low values during the Bond events (Fig. 4c, f). We therefore suggest that wet climatic conditions in the mid-high latitude region coincide with

\section{2}

7, 2159-2192, 2011

\section{Synchronicity of the East Asian Summer Monsoon}

T. Shinozaki et al.

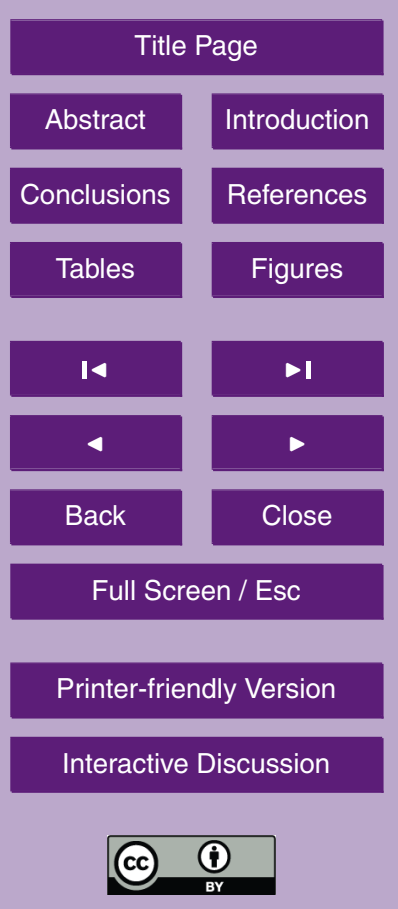


cooling events in the North Atlantic. In addition, evidence for remarkable millennial scale climate change that seems to be related the Bond events during the Holocene in East Asia using marine sediments has been reported (Isono et al., 2009; Kubota et al., 2010). Isono et al. (2009) found that the mean latitude of the Kuroshio Extension 5 has varied on a $1500 \mathrm{yr}$ periodicity during the Holocene from the alkenone SSTs in the Northwestern Pacific off Central Japan, and suggest that a climatic link exists between the North Pacific gyre system and the high-latitude North Atlantic thermohaline circulation. Kubota et al. (2010) reported that millennial scale dry (less EASM precipitation) events occurred during the Holocene from the variations in $\mathrm{Mg} / \mathrm{Ca}$-based SSTs and ${ }_{10} \delta^{18} \mathrm{O}$ of the surface water in the Northern East China Sea, suggest that a teleconnection between the EASM and the North Atlantic climate. Our results also suggest that a teleconnection existed between the Northwest Pacific region and the North Atlantic during the Holocene, and revealed that not only marine sediment but also terrestrial sediment record the climate change events related to the high-latitude North Atlantic.

The $680 \mathrm{yr}$ periodicity between 10.0 and $8.0 \mathrm{ka}$ is consistent with a prominent 649 yr cycle discovered by (Damon and Sonnett, 1991). Damon and Sonnett (1991) conducted power spectrum analysis using discrete Fourier transformation (DFT) of concatenation of La Jolla-Becker-Stuiver-Pearson ${ }^{14} \mathrm{C}$ sequence for the last $\sim 9.2 \mathrm{ka}$. They found a sharp $649 \mathrm{yr}$ periodicity, and interpreted it terms of a solar activity cycle. The $680 \mathrm{yr}$ periodicity between 10.0 and $8.0 \mathrm{ka}$ obtained from two power spectral analyses occurs at a time when summer solar insolation was strongest during the last 15 kyr (Kutzbach et al., 1998), also known as the Hypsithermal (Deevey and Flint, 1957; Davis, 1984). Already mentioned in chapter $5.2, \delta^{13} \mathrm{C}$ of Tashiro Bog is sensitive to the variability of EASM. Therefore, the EASM precipitation could be modulated by strong 25 solar output variation during the Hypsithermal. Consequently, the $680 \mathrm{yr}$ periodicity observed in the precipitation pattern of Tashiro Bog might be correlated to solar activity cycles. Moreover, the periodicity of $\delta^{13} \mathrm{C}^{\prime}$ recorded in the early Holocene could be related to high solar activity at the onset of the Hypsithermal in the Northern Hemisphere mid-high latitudes. The $680 \mathrm{yr}$ periodicity is also evident in the $\delta^{13} \mathrm{C}$ of Sphagnum peat
7, 2159-2192, 2011

\section{Synchronicity of the East Asian Summer Monsoon}

T. Shinozaki et al.

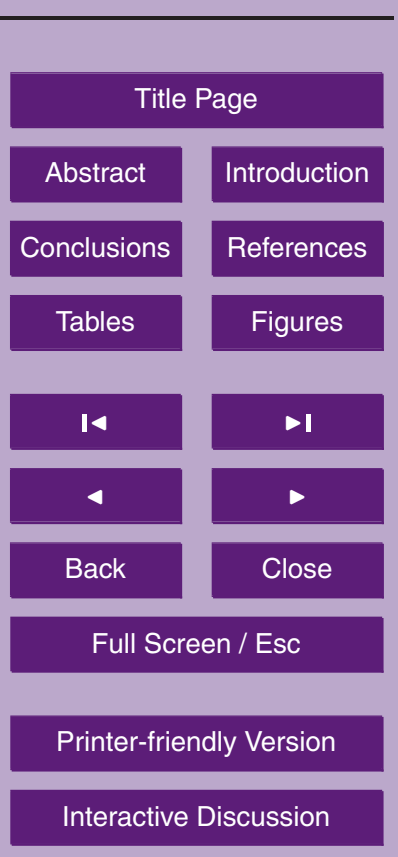

2173

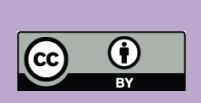


in Central China (Zhu et al., 2009). However, these periodicities are recorded between 4.0 and $1.0 \mathrm{kyr}$, which is in contrast to the $680 \mathrm{yr}$ periodicity in the Tashiro Bog, which is evident only in the early Holocene. This difference in timing might be related to the different geographical locations of the two sites. In any case, our study presents for the 5 first time evidence for the existence of a $680 \mathrm{yr}$ periodicity in the Hypsithermal in the Northwest Pacific region.

\section{Conclusions}

In order to discuss the spatial and temporal variations of the EASM in East Asia since the last deglaciation, we measured peat bulk cellulose $\delta^{13} \mathrm{C}$ collected at the Tashiro
Bog, Northeast Japan. The following results were obtained from this study:

1. The variability of peat cellulose $\delta^{13} \mathrm{C}$ records, accumulation rates and accumulation fluxes from the Tashiro Bog correspond well to abrupt climate changes recorded in the Greenland ice core between 15.5 and $8.0 \mathrm{ka}$, suggesting that the Tashiro Bog was influenced by global abrupt climate changes. $\delta^{13} \mathrm{C}$ data in the Tashiro Bog have therefore good potential as an indicator for paleoclimatic changes.

2. There is evidence for a precipitation boundary across Central China to Japan during global warm and cold periods as observed from our $\delta^{13} \mathrm{C}$ data and previous studies. While wet (dry) climatic conditions prevailed at mid-high latitudes, the mid-low latitudes were characterized by dry (wet) climatic conditions during cooling (warming) period.

3. The rain belt seems to migrate due to the global climate change. During warming periods (related to La Niña-like patterns), EASM and STH strengthen, resulting in a more southern position of the rain belt in the mid-low latitudes, and dryer conditions in the mid-high latitudes. During the cooling periods (related to El Niñolike patterns), on the other hand, EASM and STH weaken, resulting in a more 2174
7, 2159-2192, 2011

\section{Synchronicity of the East Asian Summer Monsoon}

T. Shinozaki et al.

\section{Title Page}

Abstract Introduction Conclusions References

Tables Figures
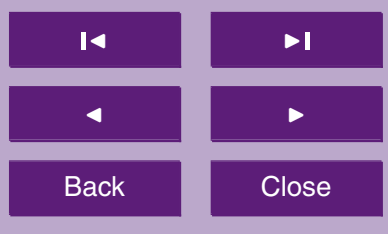

Back

Close

Full Screen / Esc

Printer-friendly Version

Interactive Discussion

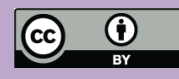


northern position of the rain belt in the mid-high latitudes, and wetter conditions in the mid-high latitudes.

4. Power spectral analyses revealed long (1230 yr) and short (580 yr and $680 \mathrm{yr}$ ) periodicities during the Holocene and the Hypsithermal, respectively. The 1230 yr periodicity seems related to Bond events, suggesting a climatic teleconnection between Northwest Pacific region and the North Atlantic. The Bond events are recorded not only in marine sediments but also in terrestrial sediments around Northwest Pacific region. The 680 yr periodicity seems related to solar activity variations and might suggest that solar activity affected precipitation during the early Holocene. Our findings propose the possibility that the EASM variability in Northwest Pacific region is synchronous to the Northern Hemisphere climate change.

Acknowledgements. We thank Y. T. Hong for providing $\delta{ }^{13} \mathrm{C}$ data from the Hani and Hongyuan Bog. We also thank A. Yoshida and K. Horiuchi for sampling the core together with authors.

15 We are grateful to T. Kobayashi, N. lida, A. Matsuda and Y. Minoura for ${ }^{14} \mathrm{C}$ measurement at NIES-TERRA. This research was supported by the Environment Research and Technology Development Fund (A-1003) of the Ministry of Environment, Japan.

\section{References}

An, Z., Porter, S. C., Weijian, Z., Yanchou, L., Donahue, D. J., Head, M. J., Xihuo, W., Jianzhang, R., and Hongbo, Z.: Episode of strengthened summer monsoon climate of Younger Dryas age on the Loess Plateau of Central China, Quarternary Research, 39, 4554, 1993.

Asada, T., Warner, B., and Aravena, R.: Nitrogen isotope signature variability in plant species from open peatland, Aquatic Botany, 82, 297-307, doi:10.1016/j.aquabot.2005.05.005, 252005.

Aucour, A.-M., Hillaire-Marcel, C., and Bonnefille, R.: Oxygen isotopes in cellulose from modern and Quatemary intertropical peatbogs: implications for palaeohydrology, Chem. Geol., 129, 341-359, 1996.
7, 2159-2192, 2011

\section{Synchronicity of the East Asian Summer Monsoon}

T. Shinozaki et al.
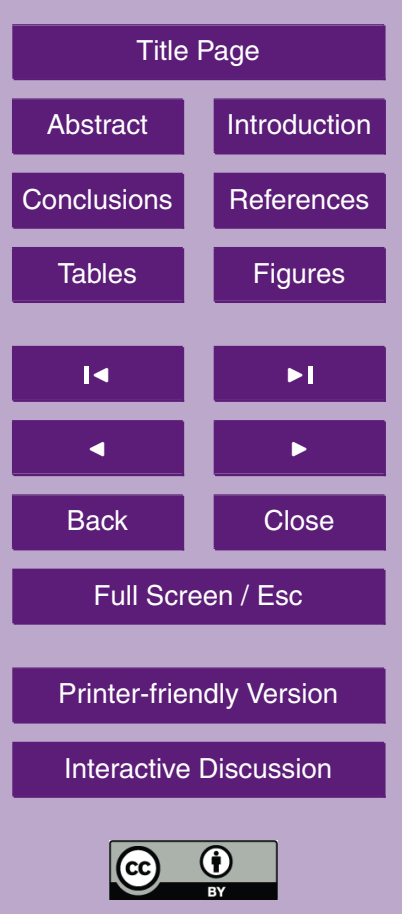
Bond, G., Showers, W., Cheseby, M., Lotti, R., Almasi, P., deMenocal, P., Priore, P., Cullen, H., Hajdas, I., and Bonani, G.: A pervasive millennial-scale cycle in North Atlantic Holocene and glacial climates, Science, 278, 1257-1266, 1997.

Bond, G., Kromer, B., Beer, J., muscheler, R., Evans, M. N., Showers, W., Hoffmann, S., Lotti5 Bond, R., Hajdas, I., and Bonani, G.: Persistent solar influence on North Atlantic climate during the Holocene, Science, 294, 2130-2136, 2001.

Brenninkmeijer, C. A. M., Geel, B. v., and Mook, W. G.: Variations in the $\mathrm{D} / \mathrm{H}$ and ${ }^{18} \mathrm{O} /{ }^{16} \mathrm{O}$ ratios in cellulose extracted from a peat bog core, Earth Planet. Sci. Lett., 61, 283-290, 1982.

Cane, M. A.: The evolution of El Niño, past and future, Earth and Planet. Sci. Lett., 230, 227$10 \quad$ 240, doi:10.1016/j.epsl.2004.12.003, 2005.

Daley, T. J., Barber, K. E., Street-Perrott, F. A., Loader, N. J., Marshall, J. D., Crowley, S. F., and Fisher, E. H.: Holocene climate variability revealed by oxygen isotope analysis of Sphagnum cellulose from Walton Moss, northern England, Quaternary Sci. Rev., 29, 15901601, doi:10.1016/j.quascirev.2009.09.017, 2010.

Damon, P. E. and Sonnett, C. P.: Solar and terrestial components of the atmospheric ${ }^{14} \mathrm{C}$ variation spectrum, in: The Sun in Time, edited by: Sonett, C. P., Tuscon: Arizona Univ Press, 360-388, 1991.

Davis, O. K.: Multiple thermal maxima during the Holocene, Science, 617-619, 1984.

Deevey, E. S. and Flint, R. F.: Postglacial Hypsithermal interval, Science, 125, 182-184, 1957.

20 Ding, Z., Nat, R., Han, J., and Liu, T.: A coupled environmetal system formed at about $2.5 \mathrm{Ma}$ in East Asia, Palaeogeogr. Palaeocl., 94, 223-242, 1992.

Dykoski, C., Edwards, R., Cheng, H., Yuan, D., Cai, Y., Zhang, M., Lin, Y., Qing, J., An, Z., and Revenaugh, J.: A high-resolution, absolute-dated Holocene and deglacial Asian monsoon record from Dongge Cave, China, Earth Planet. Sci. Lett., 233, 71-86, doi:10.1016/j.epsl.2005.01.036, 2005.

Elsig, J., Schmitt, J., Leuenberger, D., Schneider, R., Eyer, M., Leuenberger, M., Joos, F., Fischer, H., and Stocker, T. F.: Stable isotope constraints on Holocene carbon cycle changes from an Antarctic ice core, Nature, 461, 507-510, doi:10.1038/nature08393, 2009.

Fedorov, A. V. and Phillander, S. G.: Is El Niño changing?, Science, 288, 1997-2002, doi:10.1126/science.288.5473.1997, 2000.

Green, J. W.: Methods of carbohydrate chemistry, III, edited by Whistler, R. L., Academic Press, New York, NY, 9-21, 1963.

Hastenrath, S. and Greischar, L.: Circulation mechanisms related to Northeast Brazilr rainfall
7, 2159-2192, 2011

\section{Synchronicity of the East Asian Summer Monsoon}

T. Shinozaki et al.

\section{Title Page}

Abstract

Introduction

Conclusions

References

Tables

Figures
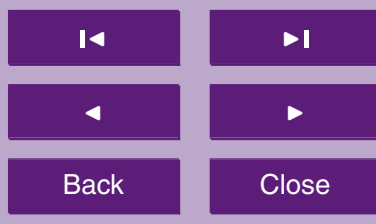

Back

Close

Printer-friendly Version

Interactive Discussion

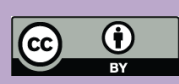


anomalies, J. Geophys. Res., 98, 5093-5102, 1993.

Haug, G. H., Hughen, K. A., Sigman, D. M., Peterson, L. C., and "hl, U. R.: Southward migration of the Intertropical Convergence Zone through the Holocene, Science, 293, 1304-1308, 2001.

5 Hayakawa, Y.: Chuseri tephra from Towada volcano, Japan (in Japanese with Englich abstract), Bulletin of the Volcanological Societ of Japan, 28, 263-273, 1983.

Hayakawa, Y.: Pyroclastic geology of Towada volcano, Bulletin of the Earthquake Research Institute, University of Tokyo, 60, 507-592, 1985.

Heslop, D., Shaw, J., Bloemendal, J., Chen, F., Wang, J., and Parker, E.: Sub-millennial scale variations in East Asian Monsoon systems recorded by dust deposits from the North-Western Chinese Loess Plateau, Physics Chem. Earth, 24, 785-792, 1999.

Hong, B., Hong, Y. T., Lin, Q. H., Shibata, Y., Uchida, M., Zhu, Y. X., Leng, X. T., Wang, Y., and Cai, C. C.: Anti-phase oscillation of Asian monsoons during the Younger Dryas period: Evidence from peat cellulose $\delta^{13} \mathrm{C}$ of Hani, Northeast China, Palaeogeogr. Palaeocl., 297, 214-222, doi:10.1016/j.palaeo.2010.08.004, 2010a.

Hong, B., Uchida, M., Leng, X. T., and Hong, Y. T.: Peat cellulose isotopes as indicators of Asian monsoon variability, PAGES news, 18, 18-20, doi:10.1016/j.quascirev.2009.09.017, 2010b.

Hong, B., Hong, Y. T., Lin, Q. H., Zhu, Y. X., Leng, X. T., Wang, Y., and Cai, C. C.: Reply to comment on "Anti-phase oscillation of Asian monsoons during the Younger Dryas period: Evidence from peat cellulose $\delta^{13} \mathrm{C}$ of Hani, Northeast China", edited by: Hong, B., Hong, Y. T., Lin, Q. H., Shibata, Y., Uchida, M., Zhu, Y. X., Leng, X. T., Wang, Y., and Cai, C. C.,Palaeogeogr. Palaeocl., 297(2010), 214-222, doi:10.1016/j.palaeo.2011.03.009, 2011.

Hong, Y., Hong, B., Lin, Q., Shibata, Y., Hirota, M., Zhu, Y., Leng, X., Wang, Y., Wang, H., and $\mathrm{Yi}, \mathrm{L}$.: Inverse phase oscillations between the East Asian and Indian Ocean summer monsoons during the last 12000 years and paleo-El Niño, Earth Planet. Sci. Lett., 231, 337346, doi:10.1016/j.epsl.2004.12.025, 2005.

Hong, Y. T., Jiang, H. B., Liu, T. S., Zhou, L. P., Beer, J., Li, H. D., Leng, X. T., Hong, B., and Qin, X. G.: Response of climate to solar forcing recorded in a 6000 -year $\delta^{18} \mathrm{O}$ time-series of Chinese peat cellulose, The Holocene, 10, 1-7, 2000.

Hong, Y. T., Wang, Z. G., Jiang, H. B., Lin, Q. H., Hong, B., Zhu, Y. X., Wang, Y., Xu, L. S., Leng, X. T., and Li, H. D.: A 6000-year record of changes in drought and precipitation in northeastern China based on a $\delta^{13} \mathrm{C}$ time series from peat cellulose, Earth Planet. Sci. Lett.,
7, 2159-2192, 2011

\section{Synchronicity of the East Asian Summer Monsoon}

T. Shinozaki et al.

\section{Title Page}

Abstract

Introduction

Conclusions

References

Tables

Figures
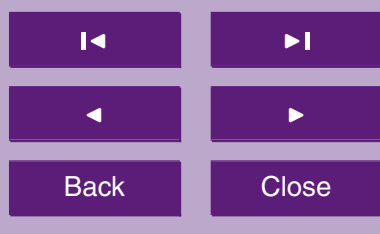

Back

Close

Printer-friendly Version

Interactive Discussion 
185, 111-119, 2001.

Hong, Y. T., Hong, B., Lin, Q. H., Zhu, Y. X., Shibata, Y., Hirota, M., Uchida, M., Leng, X. T., Jiang, H. B., and $\mathrm{Xu}, \mathrm{H}$. .: Correlation between Indian Ocean summer monsoon and North Atlantic climate during the Holocene, Earth and Planetary Science Letters, 211, 371-380, 10.1016/s0012-821x(03)00207-3, 2003.

Hong, Y. T., Hong, B., Lin, Q. H., Shibata, Y., Zhu, Y. X., Leng, X. T., and Wang, Y.: Synchronous climate anomalies in the western North Pacific and North Atlantic regions during the last 14,000 years, Quaternary Sci. Rev., 28, 840-849, doi:10.1016/j.quascirev.2008.11.011, 2009.

10 Horiuchi, K., Sonoda, S., Matsuzaki, H., and Ohyama, M.: Radiocarbon analysis of tree rings from a 15.5-cal kyr BP pyroclastically buried forest: A pilot study, Radiocarbon, 49, 11231132, 2007.

Horn, S. and Schmincke, H.-U.: Volatile emission during the eruption of Baitoushan Volcano (China/North Korea) ca. 969 AD, B. Volcanol., 61, 537-555, 2000.

15 Hu, C., Henderson, G., Huang, J., Xie, S., Sun, Y., and Johnson, K.: Quantification of Holocene Asian monsoon rainfall from spatially separated cave records, Earth Planet. Sci. Lett., 266, 221-232, doi:10.1016/j.epsl.2007.10.015, 2008.

Hughen, K. A., Overpeck, J. T., Peterson, L. C., and Trumbore, S.: Rapid climate changes in the tropical Atlantic region during the last deglaciation, Nature, 380, 51-54, 1996.

20 Ishiwatari, R., Negishi, K., Yoshikawa, H., and Yamamoto, S.: Glacial-interglacial productivity and environmental changes in Lake Biwa, Japan: A sediment core study of organic carbon, chlorins and biomarkers, Org. Geochem., 40, 520-530, doi:10.1016/j.orggeochem.2009.01.002, 2009.

Isono, D., Yamamoto, M., Irino, T., Oba, T., Murayama, M., Nakamura, T., and Kawahata, $25 \quad H$.: The 1500-year climate oscillation in the midlatitude North Pacific during the Holocene, Geology, 37, 591-594, doi:10.1130/g25667a.1, 2009.

Ivanochko, T., Ganeshram, R., Brummer, G., Ganssen, G., Jung, S., Moreton, S., and Kroon, D.: Variations in tropical convection as an amplifier of global climate change at the millennial scale, Earth Planet. Sci. Lett., 235, 302-314, doi:10.1016/j.epsl.2005.04.002, 2005.

Jackson, S. T., Charman D., Newman L., and Kiefe T.: Peatlands: Paleoenvironments and Carbon Dynamics, PAGESnews, 18(1), p. 52, 2010

Jarvis, D. I.: Pollen Evidence of Changing Holocene Monsoon Climate in Sichuan Province, China, Quarternary Research, 39, 325-337, 1993.
7, 2159-2192, 2011

\section{Synchronicity of the East Asian Summer Monsoon}

T. Shinozaki et al.

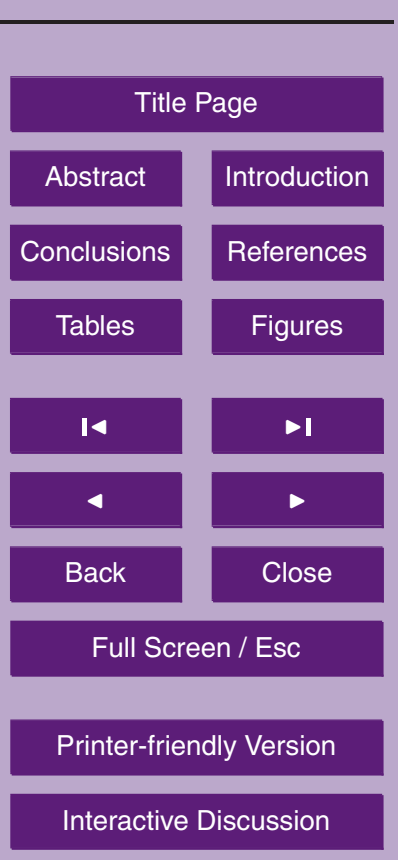


Jones, M. C., Peteet, D. M., and Sambrotto, R.: Late-glacial and Holocene $\delta^{15} \mathrm{~N}$ and $\delta^{13} \mathrm{C}$ variation from a Kenai Peninsula, Alaska peatland, Palaeogeogr. Palaeocl., 293, 132-143, doi:10.1016/j.palaeo.2010.05.007, 2010.

Koutavas, A., Lynch-Stieglitz, J., Jr., T. M. M., and Sachs, J. P.: El Niño-like pattern in ice age tropical pacific sea surface temperature, Science, 297, 226-230, doi:10.1126/science.1072376, 2002.

Kubota, Y., Kimoto, K., Tada, R., Oda, H., Yokoyama, Y., and Matsuzaki, H.: Variations of East Asian summer monsoon since the last deglaciation based on $\mathrm{Mg} / \mathrm{Ca}$ and oxygen isotope of planktic foraminifera in the northern East China Sea, Paleoceanography, 25, PA4205, doi:10.1029/2009pa001891, 2010.

Kutzbach, J., Gallimore, R., Harrison, S., Behling, P., Selin, R., and Laarif, F.: Climate and biome simulations for the past 21,000 years, Quaternary Sci. Rev., 17, 473-506, 1998.

Leuenberger, M., Siegenthaler, U., and Langway, C. C.: Carbon isotope composition of atmospheric $\mathrm{CO}_{2}$ during the last ice age from an Antarctic ice core, Nature, 357, 488-490, 1992.

Liu, T. and Ding, Z.: Chinese loess and the paleomonsoon, Annu. Rev. Earth PI. Sc., 26, 111-145, 1998.

Loader, N. J., Robertson, I., Barker, A. C., Switsur, V. R., and Waterhouse, J. S.: An improved technique for the batch processing of small wholewood samples to $\alpha$-cellulose, Chem. Geol.,

$20 \quad 136,313-317,1997$.

Ménot, G. and Burns, S. J.: Carbon isotopes in ombrogenic peat bog plants as climatic indicators: calibration from an altitudinal transect in Switzerland, Org. Geochem., 32, 233-245, 2001.

Ménot-Combes, G., Burns, S. J., and Leuenberger, M.: Variations of ${ }^{18} \mathrm{O} /{ }^{16} \mathrm{O}$ in plants from temperate peat bogs (Switzerland): implications for paleoclimatic studies, Earth Planet. Sci. Lett., 202, 419-434, 2002.

Moschen, R., Kühl, N., Rehberger, I., and Lücke, A.: Stable carbon and oxygen isotopes in sub-fossil Sphagnum: Assessment of their applicability for palaeoclimatology, Chem. Geol., 259, 262-272, doi:10.1016/j.chemgeo.2008.11.009, 2009.

Nakagawa, T., Kitagawa, H., Yasuda, Y., Tarasov, P. E., Nishida, K., Gotanda, K., Sawai, Y., and Members, Y. R. C. P.: Asynchronous Climate Changes in the North Atlantic and Japan During the Last Termination, Science, 299, 688-691, 2003.

Nakagawa, T., Tarasov, P. E., Kitagawa, H., Yasuda, Y., and Gotanda, K.: Seasonally spe-
7, 2159-2192, 2011

\section{Synchronicity of the East Asian Summer Monsoon}

T. Shinozaki et al.

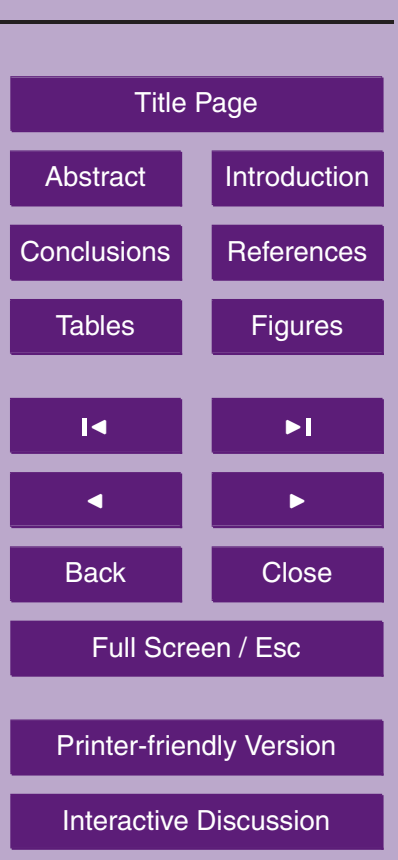


cific responses of the East Asian monsoon to deglacial climate changes, Geology, 34, 521, doi:10.1130/g21764.1, 2006.

Novak, M., Buzek, F., and Adamova, M.: Vertical trends in $\delta^{13} \mathrm{C}, \delta^{15} \mathrm{~N}$ and $\delta^{34} \mathrm{~S}$ ratios in bulk Sphagnum peat, Soil Biol. Biochem., 31, 1343-1346, 1999.

5 Oppo, D. W. and Sun, Y.: Amplitude and timing of sea-surface temperature change in the northern South China Sea: Dynamic link to the East Asian monsoon, Geology, 33, 785-788, 2005.

Paillard, D., Labeyrie, L., and Yiou, P.: Macintosh program performs time-series analysis, Eos, Transactions American Geophysical Union, 77, 379-379, 1996.

10 Porter, S. C. and An, Z.: Correlation between climate events in the North Atlantic and China during the last glaciation, Nature, 375, 305-308, 1995.

Rhodes, T. E., Gasse, F., Ruifen, L., Fontes, J.-C., Keqin, W., Bertrand, P., Gibert, E., Melieres, F., Tucholka, P., Zhixiang, W., and Zhi-Yuan, C.: A Late Pleistocene-Holocene lacustrine record from Lake Manas, Zunggar (northern Xinjiang, western China), Palaeogeogr. Palaeocl., 120, 105-121, 1996.

Rohling, E. J., Liu, Q. S., Roberts, A. P., Stanford, J. D., Rasmussen, S. O., Langen, P. L., and Siddall, M.: Controls on the East Asian monsoon during the last glacial cycle, based on comparison between Hulu Cave and polar ice-core records, Quaternary Sci. Rev., 28, 3291-3302, doi:10.1016/j.quascirev.2009.09.007, 2009.

20 Rozanski, K., Araguas-Araguas, L., and Gonfiantini, R.: Relation between long-term trends of Oxygen-18 isotope composition of precipitation and climate, Science, 258, 981-985, 1992.

Schettler, G., Liu, Q., Mingram, J., Stebich, M., and Dulski, P.: East-Asian monsoon variability between 15000 and 2000 cal. yr BP recorded in varved sediments of Lake Sihailongwan (northeastern China, Long Gang volcanic field), The Holocene, 16, 1043-1057, doi:10.1177/0959683606069388, 2006.

Schettler, G.: Comment on "Anti-phase oscillation of Asian monsoons during the Younger Dryas period: Evidence from peat cellulose $\delta^{13} \mathrm{C}$ of Hani, Northeast China", edited by: Hong, B., Hong, Y. T., Lin, Q. H. , Shibata, Y., Uchida, M., Zhu, Y. X., Leng, X. T., Wang, Y., and Cai, C. C., Palaeogeogr. Palaeocl., 297(2010), 214-222, Palaeogeogr. Palaeocl., 306, 95-97, doi:10.1016/j.palaeo.2011.02.031, 2011.

Schiegl, W. E.: Deuterium content of peat as a paleoclimatic recorder, Science, 175, 512-513, 1972.

Seki, O., Meyers, P. A., Kawamura, K., Zheng, Y., and Zhou, W.: Hydrogen isotopic ratios of 2180
7, 2159-2192, 2011

\section{Synchronicity of the East Asian Summer Monsoon}

T. Shinozaki et al.
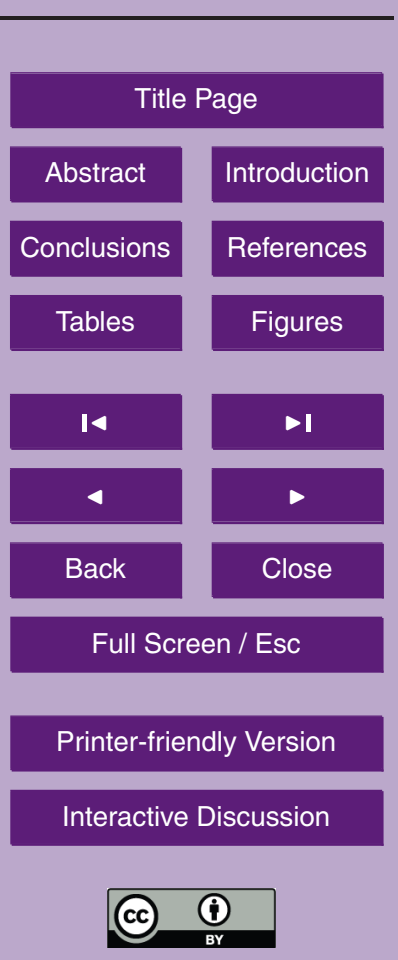
plant wax n-alkanes in a peat bog deposited in northeast China during the last $16 \mathrm{kyr}$, Org. Geochem., 40, 671-677, doi:10.1016/j.orggeochem.2009.03.007, 2009.

Siegenthaler, $\mathrm{U}$. and Oeschger, $\mathrm{H}$. : Correlation of ${ }^{18} \mathrm{O}$ in precipitation with temperature and altitude, Nature, 285, 314-317, 1980.

5 Sirocko, F., Garbe-Schonberg, D., Mcintyre, A., and Molfin, B.: Teleconnections between the subtropical monsoons and high-latitude climates during the last deglaciation, Science, 272 , 526-529, 1996.

Stebich, M., Mingram, J., Han, J., and Liu, J.: Late Pleistocene spread of (cool-)temperate forests in Northeast China and climate changes synchronous with the North Atlantic region, Global Planet. Change, 65, 56-70, doi:10.1016/j.gloplacha.2008.10.010, 2009.

Stuiver, M. and Grootes, P. M.: GISP2 oxygen isotope ratios, Quaternary Research, 53, 277284, doi:10.1006/qres.2000.2127, 2000.

Sukumar, R., Ramesh, R., Pant, R. K., and Rajagopalan, G.: A $\delta^{13} \mathrm{C}$ record of late Quaternary climate change from tropical peats in southern India, Nature, 364, 703-706, 1993.

15 Thompson, L. G., Yao, T., Davis, M. E., Henderson, K. A., Mosley-Thompson, E., Lin, P.-N., Beer, J., Synal, H.-A., Cole-Dai, J., and Bolzan, J. F.: Tropical climate instability: The last glacial cycle from a Qinghai-Tibetan ice core, Science, 276, 1821-1825, doi:10.1126/science.276.5320.1821, 1997.

Torrence, C. and Compo, G. P.: A practical guide to Wavelet Analysis, B. Am. Meteorol. Soc., 79, 61-78, 1998.

Uchida, M., Shibata, Y., Yoneda, M., Kobayashi, T., and Morita, M.: Technical progress in AMS microscale radiocarbon analysis, Nuclear Instruments and Methods in Physics Research Section B: Beam Interactions with Materials and Atoms, 223-224, 313-317, 2004.

Uchida, M., Shibata, Y., Ohkushi, K., Yoneda, M., Kawamura, K., and Morita, M.: Age discrepancy between molecular biomarkers and calcareous foraminifera isolated from the same horizons of Northwest Pacific sediments, Chem. Geol., 218, 73-89, doi:10.1016/j.chemgeo.2005.01.026, 2005.

Uchida, M., Ohkushi, K. i., Kimoto, K., Inagaki, F., Ishimura, T., Tsunogai, U., TuZino, T., and Shibata, Y.: Radiocarbon-based carbon source quantification of anomalous isotopic foraminifera in last glacial sediments in the western North Pacific, Geochem. Geophy. Geosy., 9, Q04N14, doi:10.1029/2006gc001558, 2008.

Wang, G., Feng, X., Han, J., Zhou, L., Tan, W., and Su, F.: Paleovegetation reconstruction using $\delta^{13} \mathrm{C}$ of Soil Organic Matter, Biosciences, 5, 1325-1337, 2008.
7, 2159-2192, 2011

\section{Synchronicity of the East Asian Summer Monsoon}

T. Shinozaki et al.

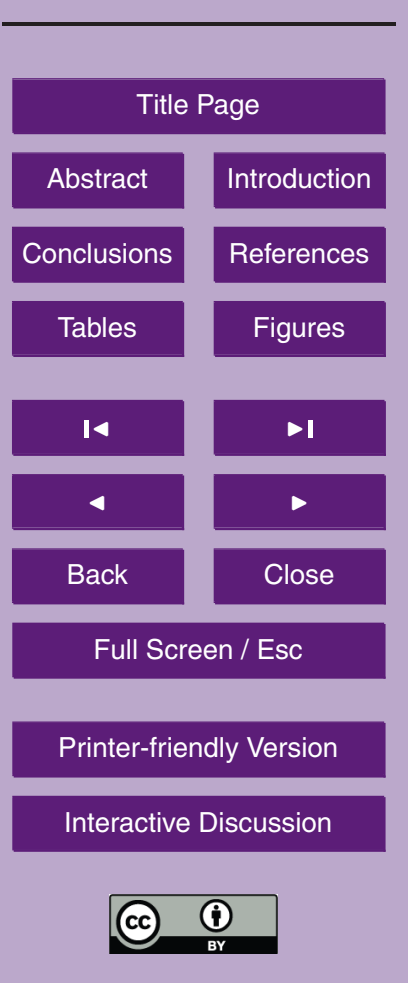


Wang, L., Sarnthein, M., Erlenkeuser, H., Grimalt, J., Grootes, P., Heilig, S., Ivanova, E., Kienast, M., Pelejero, C., and Pflaumann, U.: East Asian monsoon climate during the Late Pleistocene: high-resolution sediment records from the South China Sea, Mar. Geol., 156, 245284, 1999.

5 Wang, Y., Cheng, H., Edwards, R. L., He, Y., Kong, X., An, Z., Wu, J., Kelly, M. J., Dykoski, C. A., and Li, X.: The Holocene Asian Monsoon: Links to solar changes and North Atlantic climate, Science, 308, 854-857, doi:10.1126/science.1106296, 2005.

Wang, Y. J., Cheng, H., Edwards, R. L., An, Z. S., Wu, J. Y., Shen, C.-C., and Dorale, J. A.: A high-resolution absolute-dated Late Pleistocene monsoon record from Hulu Cave, China,

10 Science, 294, 2345-2348, doi:10.1126/science.1064618, 2001.

Wei, Z., Jibin, X., Jixiu, C., Yanming, Z., Qiaohong, M., Jun, O., Ying, C., Zhiguo, Z., and Wei, L.: Bulk organic carbon isotopic record of lacustrine sediments in Dahu Swamp, eastern Nanling Mountains in South China: Implication for catchment environmental and climatic changes in the last 16,000 years, J. Asian Earth Sci., 38, 162-169, doi:10.1016/j.jseaes.2009.12.011, 152010.

Williams, T. G. and Flanagan, L. B.: Effect of changes in water content on photosynthesis, transpiration and discrimination against ${ }^{13} \mathrm{CO}_{2}$ and $\mathrm{C}^{18} \mathrm{O}^{16} \mathrm{O}$ in Pleuroziumand Sphagnum, Oecologia, 108, 38-46, 1996.

Yamaguchi, Y. T., Yokoyama, Y., Miyahara, H., Sho, K., and Nakatsuka, T.: Synchronized Northern Hemisphere climate change and solar magnetic cycles during the Maunder Minimum, Proceedings of the National Academy of Sciences, 107, 20697-20702, doi:10.1073/pnas.1000113107/-/DCSupplemental, 2010.

Yamamoto, S., Kawamura, K., Seki, O., Meyers, P. A., Zheng, Y., and Zhou, W.: Paleoenvironmental significance of compound-specific $\delta^{13} \mathrm{C}$ variations in n-alkanes in the Hongyuan peat sequence from southwest China over the last 13ka, Org. Geochem., 41, 491-497, doi:10.1016/j.orggeochem.2010.01.006, 2010a.

Yamamoto, S., Kawamura, K., Seki, O., Meyers, P. A., Zheng, Y., and Zhou, W.: Environmental influences over the last 16ka on compound-specific $\delta^{13} \mathrm{C}$ variations of leaf wax n-alkanes in the Hani peat deposit from northeast China, Chem. Geol., 277, 261-268, doi:10.1016/j.chemgeo.2010.08.009, 2010b.

Yancheva, G., Nowaczyk, N. R., Mingram, J., Dulski, P., Schettler, G., Negendank, J. F. W., Liu, J., Sigman, D. M., Peterson, L. C., and Haug, G. H.: Influence of the intertropical convergence zone on the East Asian monsoon, Nature, 445, 74-77, doi:10.1038/nature05431,
7, 2159-2192, 2011

\section{Synchronicity of the East Asian Summer Monsoon}

T. Shinozaki et al.

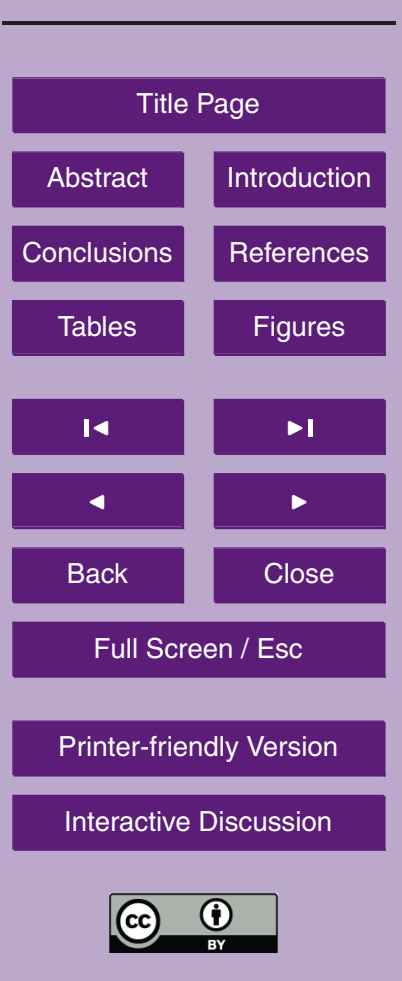


Yoshida, A., and Takeuti, S.: Quantitative reconstruction of paleoclimate from pollen profiles in northeastern Japan and the timing of a cold reversal event during the Last Termination., J. Quaternary Sci., 24, 1006-1015, 2009.

5 Yuan, D., Cheng, H., Edwards, R. L., Dykoski, C. A., Kelly, M. J., Zhang, M., Qing, J., Lin, Y., Wang, Y., Wu, J., Dorale, J. A., An, Z., and Cai, Y.: Timing, duration, and transitions of the last interglacial Asian Monsoon, Science, 304, 575-587, 2004.

Zhao, J.-X., Wang, Y.-j., Collerson, K. D., and Gagan, M. K.: Speleothem U-series dating of semi-synchronous climate oscillations during the last deglaciation, Earth Planet. Sci. Lett., 216, 155-161, 10.1016/s0012-821x(03)00501-6, 2003.

Zheng, Y., Zhou, W., Meyers, P., and Xie, S.: Lipid biomarkers in the Zoigê-Hongyuan peat deposit: Indicators of Holocene climate changes in West China, Org. Geochem., 38, 19271940, doi:10.1016/j.orggeochem.2007.06.012, 2007.

Zhou, W., Donahue, D. J., Porter, S. C., Jull, T. A., Li, X., Stuiver, M., An, Z., Matsumoto, E., and 15 Guangrong, D.: Variability of monsoon climate in East Asia at the end of the last glaciation, Quarternary Research, 46, 219-229, 1996.

Zhou, W., Xie, S., Meyers, P., and Zheng, Y.: Reconstruction of late glacial and Holocene climate evolution in southern China from geolipids and pollen in the Dingnan peat sequence, Org. Geochem., 36, 1272-1284, doi:10.1016/j.orggeochem.2005.04.005, 2005.

20 Zhou, W., Zheng, Y., Meyers, P. A., Jull, A. J. T., and Xie, S.: Postglacial climate-change record in biomarker lipid compositions of the Hani peat sequence, Northeastern China, Earth Planet. Sci. Lett., 294, 37-46, doi:10.1016/j.epsl.2010.02.035, 2010.

Zhu, Y., Chen, Y., Zhao, Z., Xiao, J., Zhang, M., Shu, Q., and Zhao, H.: Record of environmental change by $\alpha$-cellulose $\delta^{13} \mathrm{C}$ of sphagnum peat at Shennongjia, 4000-1000 aBP, Chinese
7, 2159-2192, 2011

\section{Synchronicity of the East Asian Summer Monsoon}

T. Shinozaki et al.

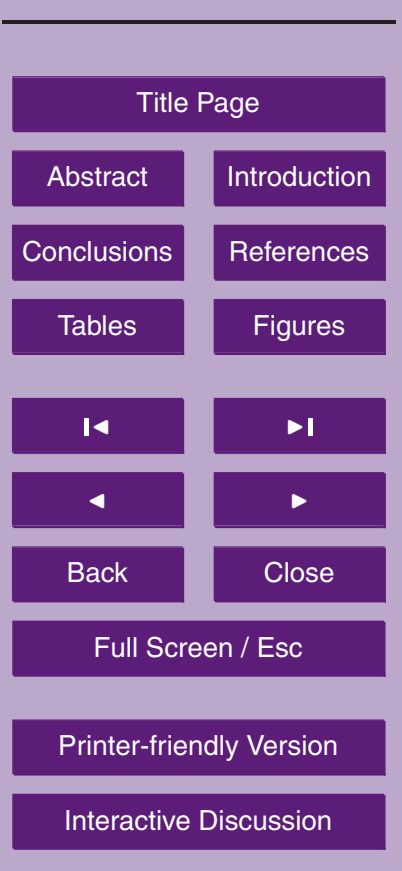


Table 1. Measured radiocarbon data of bulk sediment in core from the Tashiro Bog, Northeast Japan. Two data point, $8-10 \mathrm{~cm}$ depth and $121114 \mathrm{~cm}$ depth, are modern value (newer than AD 1950).
7, 2159-2192, 2011

\section{Synchronicity of the East Asian Summer Monsoon}

T. Shinozaki et al.

$141-142$

$181-182$

220-221

268-269

$337-338$

$347-348$

$361-362$

383-384

392-393

396-397

401-402

414-415

437-438

449-450

503-504

$533-534$

563-564

604-605

612-613

$619-620$

625-626

631-632

649-650

$667-668$

$677-678$

691-692

707-708

725-726

$739-740$

753-754

768-769

795-796

823-824

835-836

$845-846$

847-848

$847-848$
$848-849$

$-1205 \pm 24$
$-1322 \pm 32$

$1322 \pm 32$
$840 \pm 26$

$\begin{array}{r}1161 \pm 21 \\ \hline\end{array}$

$2034 \pm 23$

$2303 \pm 23$

$2862 \pm 23$

$3445 \pm 26$

$4441 \pm 27$

$4969 \pm 27$

$5010 \pm 38$

$5509 \pm 29$

$6789 \pm 33$

$6954 \pm 31$

$7111 \pm 33$

$7571 \pm 33$

$7765 \pm 36$

$8028 \pm 36$

$8595 \pm 48$

$9131 \pm 40$

$9599 \pm 46$

$9889 \pm 40$

$10051 \pm 46$

$10116 \pm 40$

$10289 \pm 45$

$10432 \pm 38$

$10456 \pm 42$

$10652 \pm 34$

$10861 \pm 40$

$11042 \pm 33$

$11396 \pm 58$

$11624 \pm 50$

$11849 \pm 41$

$12048 \pm 50$

$12188 \pm 42$

$12324 \pm 43$

$12447 \pm 46$

$12555 \pm 45$

$12655 \pm 47$

$12865 \pm 50$

$13005 \pm 45$

$12951 \pm 40$
Calendar age Lab. Code

(cal yr BP) $(1 \sigma)$

-37 (modern) TERRA-113009a20

726-781 TERRA-120709a03

1054-1091 TERRA-020410a12

1947-2003 TERRA-120209a18

2330-2348 TERRA-120209a19

3681-3723 TERRA-120209a21

4971-5054 TERRA-120209a23

5658-5720 TERRA-020410a13

5697-5752 TERRA-112609a36

6281-6317 TERRA-113009a22

7610-7665 TERRA-113009a23

7739-7831 TERRA-120709a05

7931-7969 TERRA-120709a06

8371-8406 TERRA-113009a24

8536-8592 TERRA-113009a25

8972-9010 TERRA-120709a08

9524-9599 TERRA-113009a26

10230-10297 TERRA-113009a27

10790-10968 TERRA-113009a28

11238-11314 TERRA-120709a09

11463-11564 TERRA-091709a31

11688-11825 TERRA-111809a02

11982-12147 TERRA-091709a32

12235-12324 TERRA-120709a11

12450-12610 TERRA-111809a03

12700-12786 TERRA-091509a33

12 833-12872 TERRA-120709a12

12904-12995 TERRA-091509a34

13207-13309 TERRA-112609a35

13392-13549 TERRA-091709a35

13676-13771 TERRA-090809a27

13832-13963 TERRA-120709a13

13990-14106 TERRA-111809a04

14091-14320 TERRA-120709a14

14269-14647 TERRA-111809a29

14627-14940 TERRA-090809a29

14810-15065 TERRA-090809a30

15110-15518 TERRA-020410a15

15203-15491 TERRA-090809a31

2184
Title Page

Abstract

Introduction

Conclusions

References

Tables

Figures

14

Back

Close

Full Screen / Esc

Printer-friendly Version

Interactive Discussion

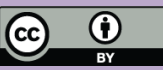




Table 2. The list of the research for mosoonal precipitation around East Asia during cold period. From 1 to 9 shows it was wetter environment. From 10 to 19 shows it was drier environment. $8.2 \mathrm{ka}, \mathrm{YD}, \mathrm{LIA}$, OlderD/GI and LGM represent $8.2 \mathrm{ka}$ cold event, Younger Dryas cold period, Little Ice Age, Older Dryas/Greenland Interstadial and Last Glacial Maximum, respectively.

\begin{tabular}{|c|c|c|c|}
\hline Reference & Regions & Proxy & Periods \\
\hline 1. This study & Northeastern Japan (Tashiro Bog) & $\delta^{13} \mathrm{C}$ of peat bulk cellulose & ex. 8.2ka, YD \\
\hline 2. Yamaguchi et al. (2010) & Central Japan & $\delta^{18} \mathrm{O}$ of tree-ring & LIA \\
\hline 4. Nakagawa et al. (2006) & Central Japan (Lake Suigetsu) & pollen data of lake sediment & YD \\
\hline 5. Hong et al. (2005) & Northeastern China (Hani Bog) & $\delta^{13} \mathrm{C}$ of peat bulk cellulose & YD \\
\hline 6. Zhou et al. (2010) & Northeastern China (Hani Bog) & $n$-alkane data of peat & YD \\
\hline 9. An et al. (1993) & Central China (Baxie Loess) & dust Mugnetic Susceptibility & YD \\
\hline 10. Schettler et al. (2006) & Northeastern China (Lake Sihailongwan) & geochemical data of lake sediment & YD \\
\hline 11. Stebich et al. (2009) & Northeastern China (Lake Sihailongwan) & pollen data of lake sediment & OlderD/GI \\
\hline 12. Kubota et al. (2010) & East China Sea & foraminifera $\mathrm{Mg} / \mathrm{Ca}, \delta^{18} \mathrm{O}$ & IRD-events \\
\hline 13. Zhao et al. (2003) & Eastern China (Tangshan Cave) & $\delta^{18} \mathrm{O}$ of stalagmite & YD, LGM \\
\hline 14. Wang et al. (2001) & Eastern China (Hulu Cave) & $\delta^{18} \mathrm{O}$ of stalagmite & ex. YD \\
\hline 18. Wei et al. (2010) & Southern China Mainland (Dahu Swamp) & $\delta^{13} \mathrm{C}_{\text {org }}$ of lacustrine sediment & YD \\
\hline 19. Wang et al. (1999) & South China Sea & foraminifera $\delta^{18} \mathrm{O}, \delta^{13} \mathrm{C}$ & YD \\
\hline
\end{tabular}

Synchronicity of the East Asian Summer Monsoon

T. Shinozaki et al.
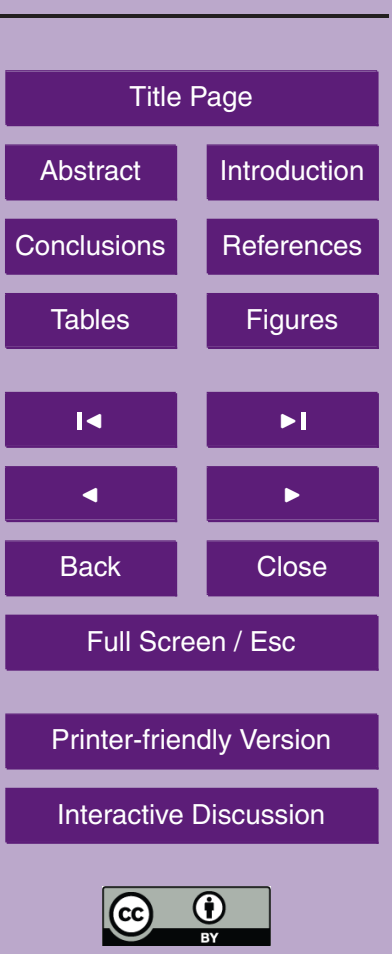


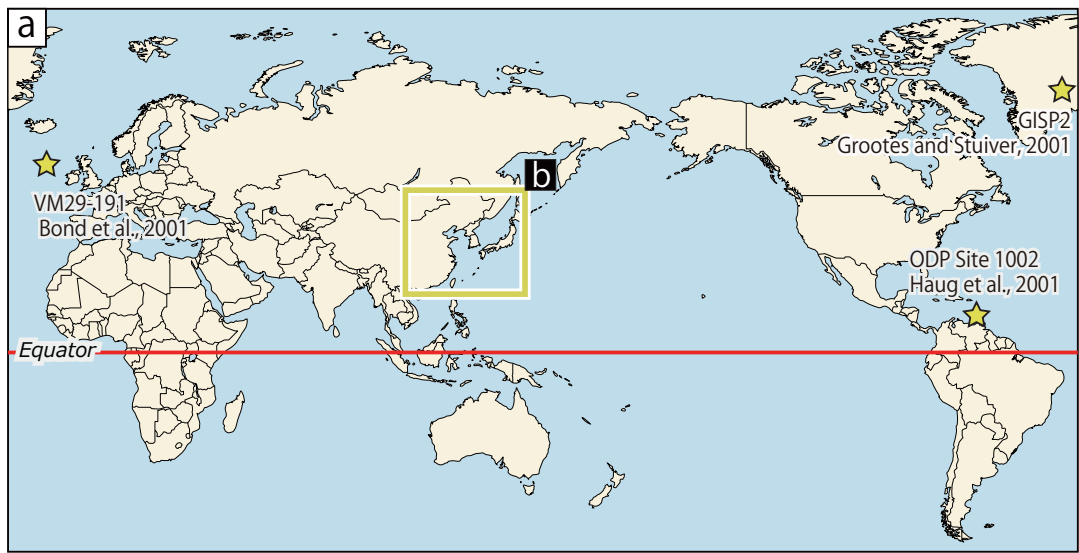

7, 2159-2192, 2011

\section{Synchronicity of the East Asian Summer Monsoon}

T. Shinozaki et al.

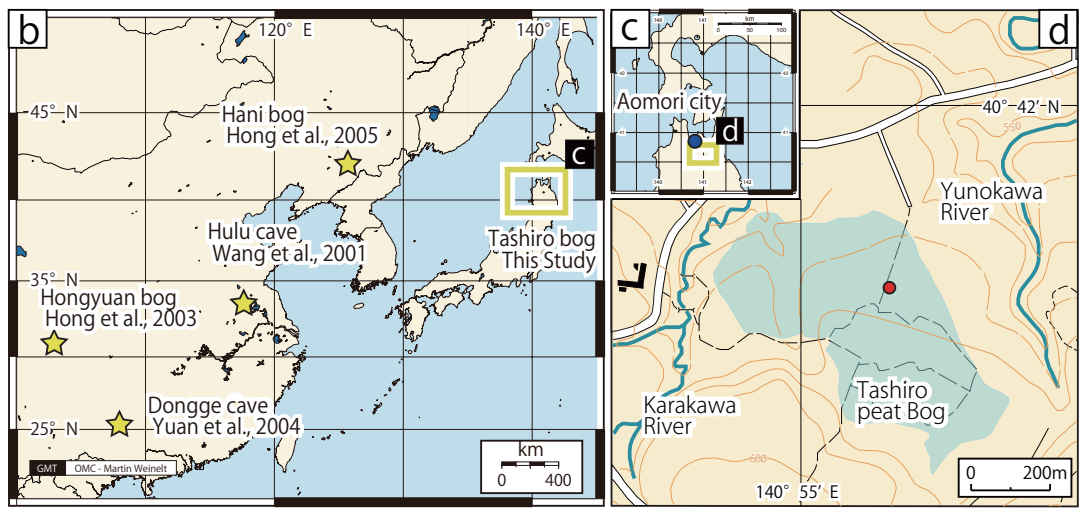

Title Page

Abstract

Introduction

Conclusions

References

Tables

Figures

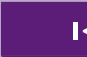

14

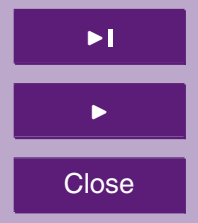

Back

Close

Full Screen / Esc

Printer-friendly Version

Fig. 1. Location of the study area and other reference sites (yellow star). The blue circle indicates Aomori city in Fig. 1c. The red circle indicates the coring point in Fig. 1d.

Interactive Discussion 
(a) Calendar Age (cal kyr BP)

(b) Total Organic Carbon (\%)

(c) Dry Bulk Dencity $\left(\mathrm{mg} \mathrm{cm}^{-3}\right)$



Fig. 2. Core lithology, and depth profile of (a) calendar age (cal kyr BP), (b) TOC (\%) and (c) DBD $\left(\mathrm{mg} \mathrm{cm}^{-3}\right)$. Yellow bands represent the ash layers.
Synchronicity of the East Asian Summer Monsoon

T. Shinozaki et al.

Title Page

\section{Abstract}

Introduction

Conclusions

References

Tables

Figures

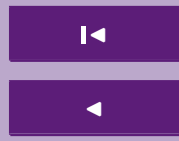

Back

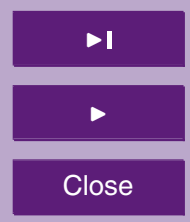

Full Screen / Esc

Printer-friendly Version

Interactive Discussion

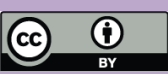




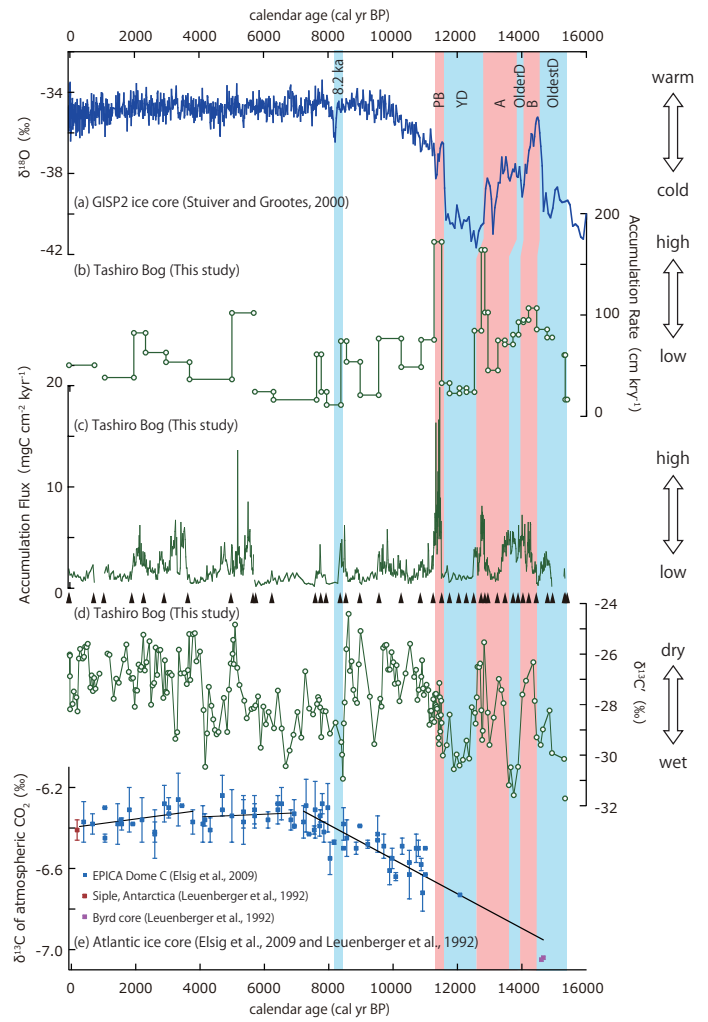

Fig. 3. Variation in (a) GISP2 ice core $\delta^{18} \mathrm{O}$ (Stuiver and Grootes, 2000), (b) accumulation rate at Tashiro Bog (This study), (c) accumulation flux at Tashiro Bog (This study), (d) $\delta^{13} \mathrm{C}^{\prime}$ at Tashiro Bog (This study) and (e) $\delta^{13} \mathrm{C}$ variability of atmospheric $\mathrm{CO}_{2}$ (Elsig et al., 2009; Leuenberger et al., 1992) since 16000 to $-60 \mathrm{cal}$ yr BP. Black triangles indicate ${ }^{14} \mathrm{C}$ age control point. $8.2 \mathrm{ka}, \mathrm{PB}, \mathrm{YD}, \mathrm{A}$, OlderD, B and OldestD represent $8.2 \mathrm{ka}$ cold event, Preboreal warming, Yonger Dryas cold period, Allerød warm period, Older Dryas, Bølling warm period and Oldest Dryas, respectively.
7, 2159-2192, 2011

\section{Synchronicity of the East Asian Summer Monsoon}

T. Shinozaki et al.

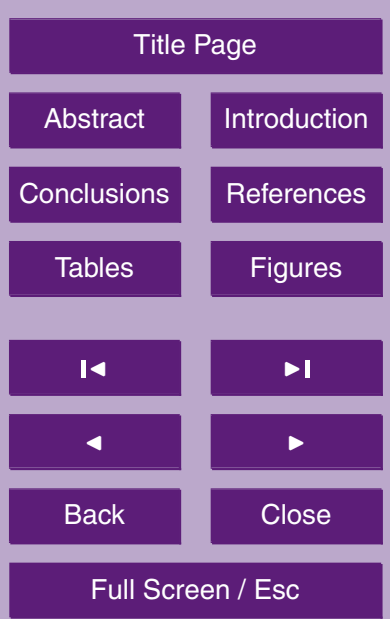

Printer-friendly Version

Interactive Discussion

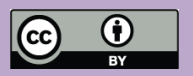




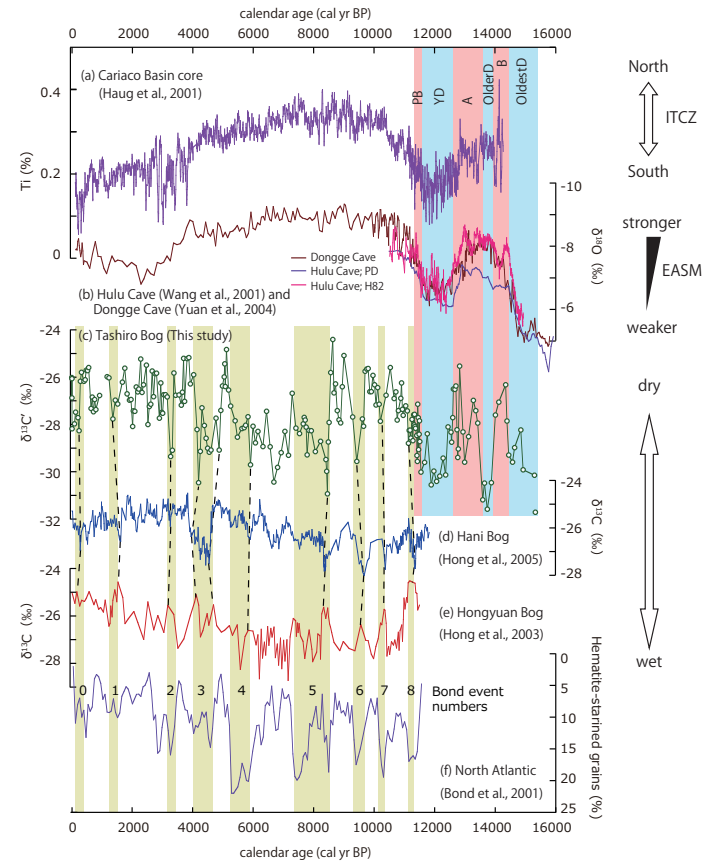

\section{Synchronicity of the East Asian Summer Monsoon}

T. Shinozaki et al.

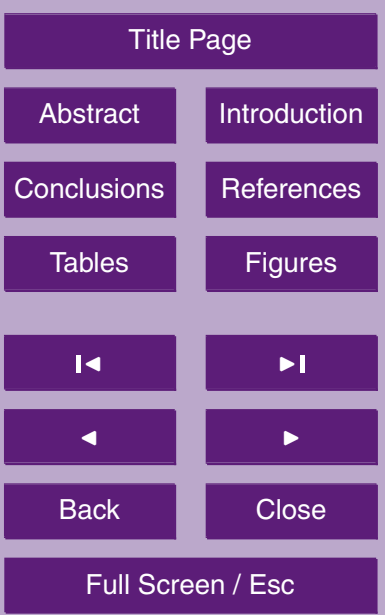

Printer-friendly Version

Interactive Discussion indicate the period of IRD-events. PB, YD, A, OlderD, B and OldestD represent Preboreal warming, Yonger Dryas cold period, Allerød warm period, Older Dryas, Bølling warm period and Oldest Dryas, respectively.

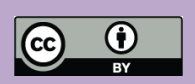




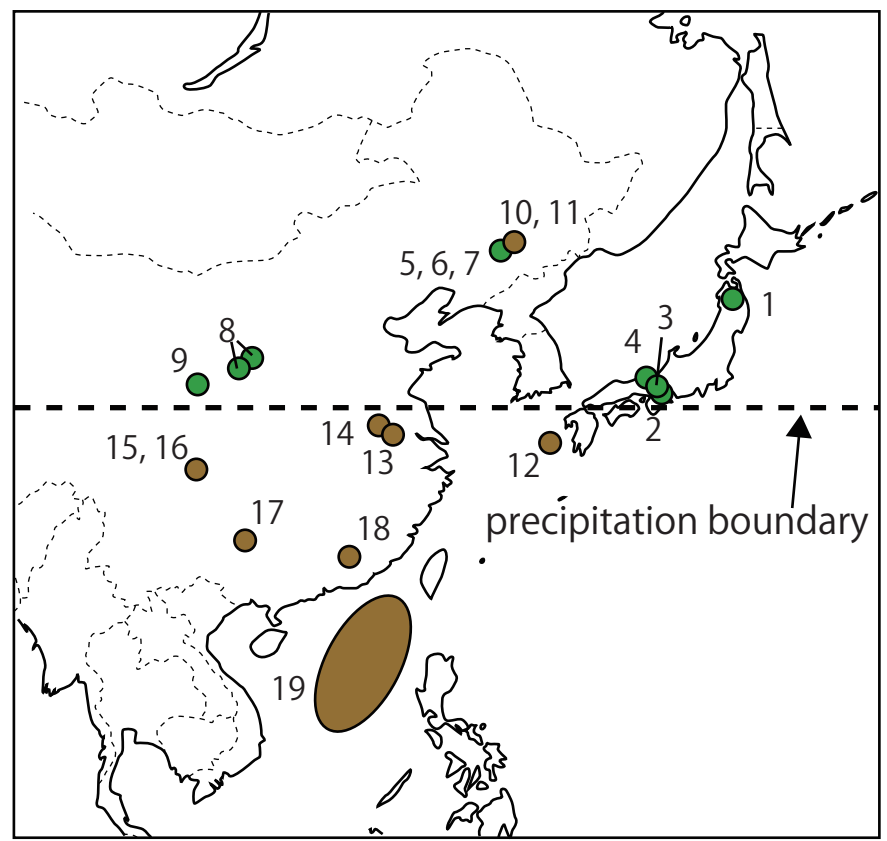

\section{Synchronicity of the East Asian Summer Monsoon}

T. Shinozaki et al.

Title Page

Abstract

Introduction

Conclusions

References

Tables

Figures
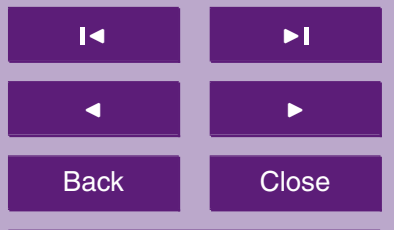

Back

Close

Fig. 5. Sketch maps showing the location of research site for monsoonal precipitation during cold period. Green and brown circles show wetter and dryer conditions, respectively, during this period. These numbers correspond to the reference numbers of Table 2.

Full Screen / Esc

Printer-friendly Version

Interactive Discussion

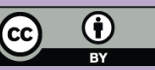




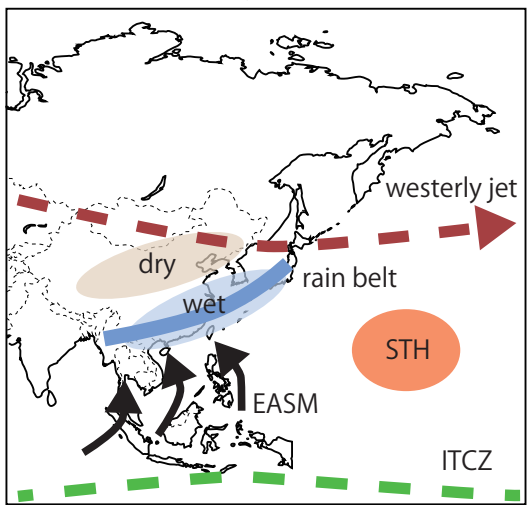

(b) Global warming period

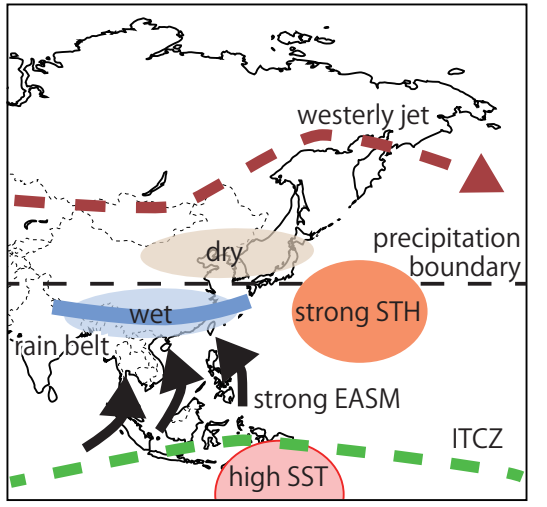

(c) Global cooling period

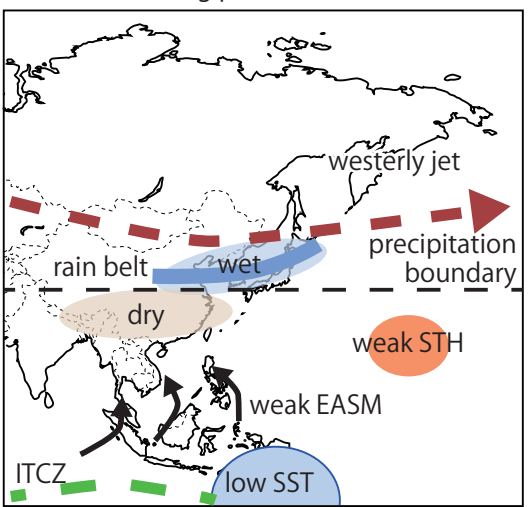

Fig. 6. Sketch maps showing the (a) todays mean meteorological feature in summer and paleometeorological features during (b) global warming period and (c) global cold period over East Asia.
7, 2159-2192, 2011

\section{Synchronicity of the East Asian Summer Monsoon}

T. Shinozaki et al.

Title Page

\begin{tabular}{c|c|}
\hline Abstract & Introduction \\
\hline Conclusions & References \\
\hline Tables & Figures \\
\hline I4 & $\bullet$ \\
\hline 4 & $\triangleright$ \\
\hline Back & Close \\
\hline Full Screen / Esc
\end{tabular}

Printer-friendly Version

Interactive Discussion

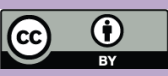




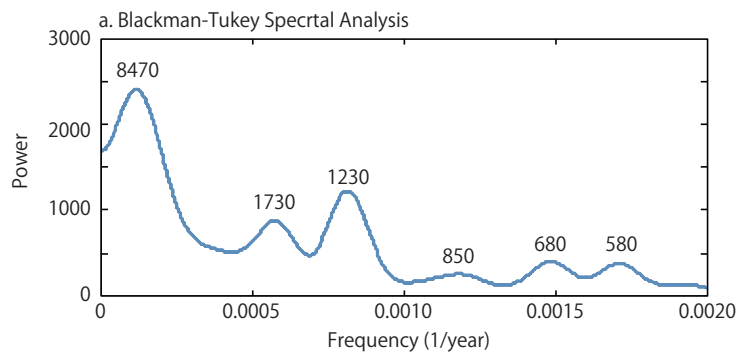

\section{Synchronicity of the East Asian Summer Monsoon}

T. Shinozaki et al.

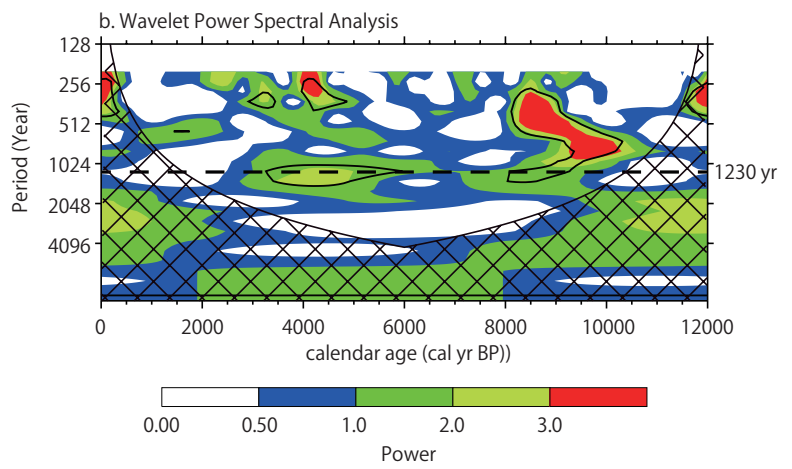

Title Page

\begin{tabular}{|c|c|}
\hline Abstract & Introduction \\
\hline Conclusions & References \\
\hline Tables & Figures \\
\hline I4 & $\bullet$ \\
\hline 4 & - \\
\hline Back & Close \\
\hline Full Screen / Esc
\end{tabular}

Fig. 7. Results of two type spectral analyses. (a) The Blackman-Tukey Spectral Analysis. Numbers above peaks indicate the corresponding periodicities (years). (b) Wavelet Power Spectral Analysis using the Morlet wavelet. The y-axis is the wavelet period in years. The shaded contours are at normalized variances. The thick contours are the $10 \%$ significance regions. The dashed line indicates the characterized periodicity, $1230 \mathrm{yr}$, which is also shown in Black-Tukey Spectral Analysis.

Printer-friendly Version

Interactive Discussion 